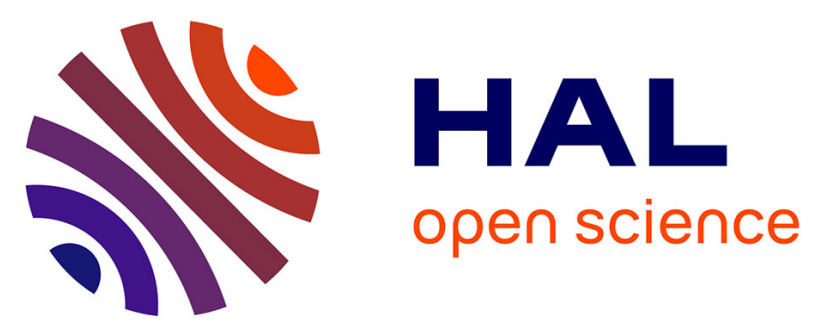

\title{
Décollements, Detachments, and Rafts in the Extended Crust of Dangerous Ground, South China Sea: The Role of Inherited Contacts
}

Yao Liang, Matthias Delescluse, Yan Qiu, Manuel Pubellier, Nicolas

Chamot-Rooke, Jun Wang, Xie Nie, Louise Watremez, Sung-Ping Chang, Thibaud Pichot, et al.

\section{To cite this version:}

Yao Liang, Matthias Delescluse, Yan Qiu, Manuel Pubellier, Nicolas Chamot-Rooke, et al.. Décollements, Detachments, and Rafts in the Extended Crust of Dangerous Ground, South China Sea: The Role of Inherited Contacts. Tectonics, 2019, 38 (6), pp.1863-1883. 10.1029/2018TC005418 . hal02324022

\section{HAL Id: hal-02324022 \\ https://hal.science/hal-02324022}

Submitted on 21 Oct 2019

HAL is a multi-disciplinary open access archive for the deposit and dissemination of scientific research documents, whether they are published or not. The documents may come from teaching and research institutions in France or abroad, or from public or private research centers.
L'archive ouverte pluridisciplinaire $\mathbf{H A L}$, est destinée au dépôt et à la diffusion de documents scientifiques de niveau recherche, publiés ou non, émanant des établissements d'enseignement et de recherche français ou étrangers, des laboratoires publics ou privés. 


\section{Tectonics}

\section{RESEARCH ARTICLE 10.1029/2018TC005418 \\ Key Points: \\ - We investigate the crustal structure of the Dangerous Ground, southern South China Sea, using multichannel and refraction seismic data \\ - Extensional deformation localizes on a $10-15-\mathrm{km}$ offset crustal detachment thinning the crust from 20 to $15 \mathrm{~km}$ \\ - The detachment activity was a breakup propagation attempt along a reactivated contact bounding Mesozoic, arc-related granitic plutons}

Supporting Information:

- Supporting Information S1

Correspondence to:

Y. Liang and M. Delescluse,

liangyao@mail.iggcas.ac.cn;

delescluse@geologie.ens.fr

Citation:

Liang, Y., Delescluse, M., Qiu, Y., Pubellier, M., Chamot-Rooke, N., Wang, J., et al. (2019). Décollements, detachments, and rafts in the extended crust of Dangerous Ground, South China Sea: The role of inherited contacts. Tectonics, 38, 1863-1883. https://doi.org/10.1029/2018TC005418

Received 15 NOV 2018 Accepted 30 APR 2019

Accepted article online 8 MAY 2019

Published online 12 JUN 2019

(c)2019. American Geophysical Union. All Rights Reserved.

\section{Décollements, Detachments, and Rafts in the Extended Crust of Dangerous Ground, South China Sea: The Role of Inherited Contacts}

\author{
Yao Liangi, ${ }^{1,2}$, Matthias Delescluse ${ }^{1}$ (D), Yan Qiu3 ${ }^{3}$, Manuel Pubellier' ${ }^{1}$, Nicolas Chamot-Rooke ${ }^{1}$ (D), \\ Jun Wang ${ }^{3}$, Xie Nie ${ }^{3}$, Louise Watremez ${ }^{4}\left(\mathbb{D}\right.$, Sung-Ping Chang ${ }^{1}$ (D), Thibaud Pichot ${ }^{1,5}$, \\ Dimitri Savva ${ }^{1,5}$, and Florian Meresse ${ }^{1}$ \\ ${ }^{1}$ Laboratoire de Géologie, Ecole Normale Supérieure, CNRS UMR 8538, PSL Research University, Paris, France, ${ }^{2}$ Now at \\ Institute of Geology and Geophysics, Chinese Academy of Science, Beijing, China, ${ }^{3}$ Guangzhou Marine Geological Survey, \\ Guangzhou, China, ${ }^{4}$ Université de Lille, CNRS, Université Littoral Côte d'Opale, UMR 8187, Laboratoire d'Océanologie et \\ de Géosciences, Lille, France, ${ }^{5}$ Now at Beicip-Franlab, Rueil-Malmaison, France
}

\begin{abstract}
We investigate the crustal structure of the Dangerous Ground (South China Sea) through processing and interpretation of coincident wide-angle reflection and refraction seismic data. Continental crust of Dangerous Ground has been moderately thinned, down to $15 \mathrm{~km}$, so that most of the structures accompanying the early opening of the South China Sea from Cretaceous to Miocene have been preserved. Subbasement reflectors as well as refraction velocities image an interpreted dismantled Mesozoic metamorphic unit in the southernmost section of our study area. A rollover structure indicates that the reflective base of the unit was used as a décollement where low-angle normal faults root and blocks rafted. The metamorphic unit is discontinued in a nearby basin located immediately to the north, where the refraction velocity model shows thinning of the crust from 20 to $15 \mathrm{~km}$, with the presence of a 5-km-high mantle dome. In this deeper basin, mass transport deposits are found lying on a strong amplitude basement reflector interpreted as the footwall of an $\sim 15 \mathrm{~km}$ offset crustal detachment surface that we link down to the mantle dome. We infer that the detachment reactivated an inherited low-angle contact most probably related to the Yanshanian belt. In map view, the reactivated structure forms a half-graben basin oriented NNE-SSW oblique to the generally accepted direction of extension. This orientation follows the general trend of a granitic belt that spanned the South China margin prior to extension, related to the subduction of the Paleo-Pacific.
\end{abstract}

\section{Introduction}

The South China Sea (SCS) is an intensely studied marginal basin where extensional processes and structures cannot easily be explained in the light of classic end-member concepts of magma poor and magma rich margins (Larsen et al., 2018). In the SCS, successive rifting phases lead to a rather constant crustal thickness (Pichot et al., 2014) over a particularly wide rifted area (Franke et al., 2014). The SCS margin features both occasional mantle exhumation (McIntosh et al., 2014; Savva et al., 2013) and basaltic magmatism during breakup (Larsen et al., 2018) with narrow continent-ocean transition (Cameselle et al., 2015; Pichot et al., 2014).

A succession in time of tilting allows distinguishing several thinning events (e.g., Ding et al., 2013; Franke et al., 2014; Savva et al., 2014) following a stretching event mostly observed in the coastal strip of Guangdong and Guangxi Provinces of China as well as in the Pearl River basin (Chan et al., 2010). This early extension along the Eastern SCS margin is generally considered to have started in the Late Cretaceous/Paleocene time (Franke et al., 2014; Sun et al., 2006; Sun et al., 2009), and the main continental rifting phase was a short Late Eocene event $(<10 \mathrm{Myr})$ according to recent drilling results (Larsen et al., 2018). Rifting was followed by Oligo-Miocene oceanic spreading from 32 to $15 \mathrm{Ma}$ (Briais et al., 1993; $\mathrm{Li}$ et al., 2014; Taylor \& Hayes, 1980, 1983), or 32 to 20 Ma (e.g., Barckhausen et al., 2014). In the Eastern Basin, breakup occurred abruptly in time and space under the effect of an overall westward propagation of the accreting centers (Cameselle et al., 2015). From 33 to $23.5 \mathrm{Ma}$, spreading first occurred in the eastern Basin only, because of a propagation stalling phase possibly related to far-field boundary conditions ahead of the propagator (Le Pourhiet et al., 2018). During that time, the Eastern Basin experienced several southward 

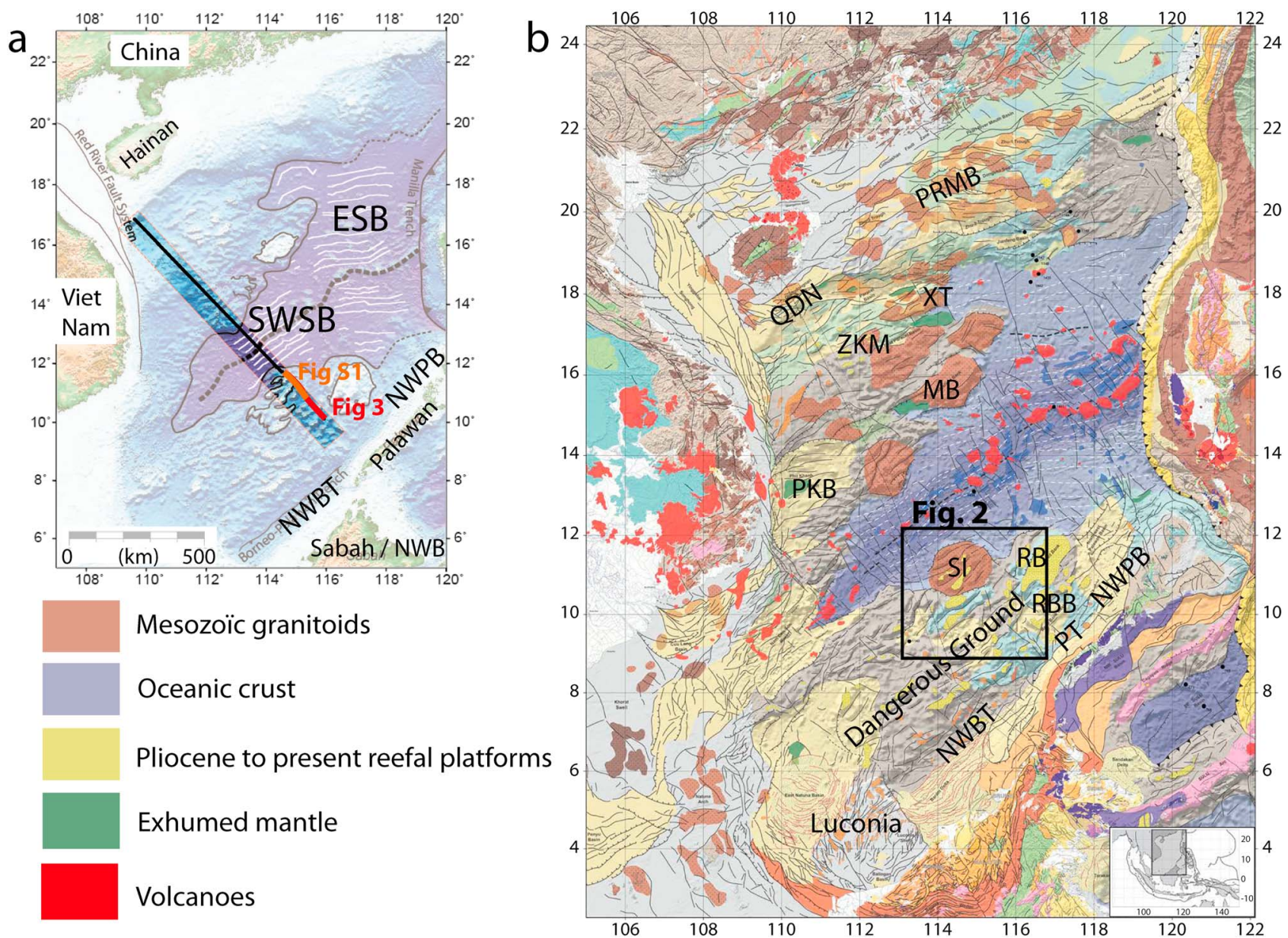

Figure 1. (a) The 1,000-km-long seismic line in the South China Sea with positions of the 50 OBSs (Pichot et al., 2014). The 230-km-long section of the profile across Spratly Islands is indicated in red and orange. SWSB = Southwest subbasin, ESB = Eastern sub-basin. (b) Extract of the structural map of the South China Sea (Pubellier et al., 2016). M.B. = Macclesfield Bank (Zhongsha Islands), NWBT $=$ NW Borneo Trough, NWPB $=$ NW Palawan Basin, PKB $=$ Phu Khan Basin, PRMB = Pearl River Mouth Basin, PT = Palawan "Trench,” QDN = Quiondongnan Basin, RB = Reed Bank, RBB = Reed Bank Basin, SI = Spratly Islands (Zenghe High, Nansha Islands), XT = Xisha Trough, ZKM = Zongsha-Xisha Massif. The black frame shows the location of Figure 2.

ridge jumps (Ding et al., 2018), after which the spreading head finally propagated to the southwest. This last phase resulted in the opening of the Southwest subbasin (SWSB) between 23.5 and 16 Ma (Huchon et al., 2001; Li et al., 2014; Sibuet et al., 2016) with reduced magma supply (Yu et al., 2017; Yu et al., 2018). These successive rifting/opening events lead to the overall characteristic $V$-shaped morphology observed today (Briais et al., 1993; Ding \& Li, 2016; Huchon et al., 1998, 2001; Li et al., 2012; Taylor \& Hayes, 1983). The SWSB (Figure 1) conjugate margins feature the widest extended continental crust area (hundreds of kilometers), stretched while oceanic propagation stalled in the Eastern Basin (Le Pourhiet et al., 2018). Fast breakup propagation resumed only after a stress change (Sibuet et al., 2016) toward a more favorable direction of extension leading to spreading in the SWSB.

Regarding the structural style of rifting, most published seismic lines indicate the presence of listric faults rooting apparently at different structural levels, either in the upper crust or deep into the lower crust. Ductile flow in the lower crust can explain the relative flatness of the Moho and rather constant crustal thickness over hundreds of kilometers (Pichot et al., 2014). Meanwhile, areas of exhumed mantle associated with very severe stretching are bounded by tilted blocks of upper crust rafting over a highly thinned lower crust, sometimes welded to the mantle where lower crust has been totally removed (e.g., Savva et al., 2013). Basin-sized tilted blocks are widespread over the northern margin, including the Xisha Trough, the Bayung Sag, and the Qiongdongnan Basin among others (Franke et al., 2014). The apparent contradiction between a generally distributed extension and more significant but localized extension in a few basins 
raises the question of the possible reactivation of inherited structures such as Mesozoic granites, or even contacts within the sedimentary pile such as erosional surfaces or fold flanks (Savva et al., 2014; Yan et al., 2011).

In this study, we focus on an area located in the north-east of Dangerous Ground, south of the oceanic basins and at the eastern boundary of the Southwest subbasin (Figure 1). The Eocene-Oligocene restored position of the basins in this area would locate them close to the Xisha Trough (Gao et al., 2016) and other hyperextended basins (Figure 1, green areas) that were abandoned on the northern margin, suggesting that all these basins are genetically linked. At variance with Xisha Trough, which shows important accumulation of Cretaceous and Tertiary sediments and occurrences of mantle or magmatic intrusions (Lei et al., 2015), stretching was less severe in these southern basins since mantle was not exhumed.

We present the reprocessing and the interpretation of multichannel seismic data and coincident refraction data acquired through a Sino-French collaboration between the Guangzhou Marine Geological Survey and Ecole Normale Supérieure in Paris. The coincident profiles cross a rather unexplored basin located between Reed Bank and the Spratly Islands (Nansha Block). We make use of both the deep reflectivity and refraction velocity down to mantle to unravel extensional structures and processes, and discuss them in the local and general framework of the South China Sea opening. We aim to understand why thinning was limited in this area of Dangerous Ground when compared to its northern counterpart. We also take advantage of an area where the frozen early processes of opening were not obliterated by further stretching to try to better understand the early structures and localization processes in the broader framework of extensional tectonics.

\section{Geological Background: Dangerous Ground}

The Dangerous Ground (Nansha Qundao in Chinese, we follow here the toponymy of Hutchison and Vijayan (2010)) is a set of shoals dotting the southern South China Sea (250 major islands and hundreds more of smaller size), most of them being carbonate buildups that kept up with the subsidence since at least the Miocene (Hutchison \& Vijayan, 2010). The area $\left(135,000 \mathrm{~km}^{2}\right.$, about the size of England) broadly stretches along a NE trend from central Luconia in the south to Reed Bank in the north (Figure 1). It is generally seen as the preserved southern passive margin of the South China Sea, which, to some extent, remained away from the south subduction/obduction deformation in Sarawak, Borneo, Sabah, and Palawan.

Based on geodynamic reconstructions supported by the identification of magnetic lineation in the oceanic basins of the South China Sea, it is agreed that massifs that form Dangerous Ground today, together with North Palawan, Reed Bank, and part of the Philippines, were former continental microblocks attached to South China mainland in Cretaceous time (e.g., Holloway, 1981; Holloway, 1982; Taylor \& Hayes, 1980, 1983; and all subsequent reconstructions). These blocks migrated southward in the wake of the opening of South China Sea oceanic basins (East Basin and Southwest Basin), while others, such as the Macclesfield Bank or the Zongsha-Xisha Massif (Figure 1), were abandoned on the northern margin (see Cullen et al., 2010, for an update of the physiographic provinces and a review of their tectonic significance). Dangerous Ground evolution is thus tightly linked to the progressive opening of the South China Sea from east to west, that is, rifting and early drifting of the East Basin in Oligocene, stalling phase, westward propagation of the ridge tip, and further opening of the SW subbasin in the Miocene. Dangerous Ground was rifted while the East Basin was opening, until the head of the westward propagating ridge passed through to open to the SW subbasin (Franke et al., 2014). Carbonate built onto the head of tilted blocks, eventually enhancing the "Basin and Range" type morphology recognized today in bathymetry and in the gravity field as short NE trending segments (Hutchison \& Vijayan, 2010). Some of these buildups apparently grew onto transverse structures active during rifting (Cullen et al., 2010). First-order features of Dangerous Ground thus relate to the recent (Paleogene) extensive phases, but the area has a far much longer geological history shared with South China.

Based on extensive dredging (Hinz \& Schlüter, 1985; Kudrass et al., 1986; Yan et al., 2010; reviewed in Hutchison \& Vijayan, 2010), the present-day crystalline basement of Dangerous Ground seems to be mainly composed of an assemblage of metamorphic rocks (up to the amphibolite facies) and igneous bodies (rhyolites, diorites, gabbros) of Mesozoic age. The oldest datable sediment within Dangerous Ground is a Late Triassic/Early Jurassic deltaic sandstone dredged along the wall of a half-graben some $20 \mathrm{~km}$ off the 


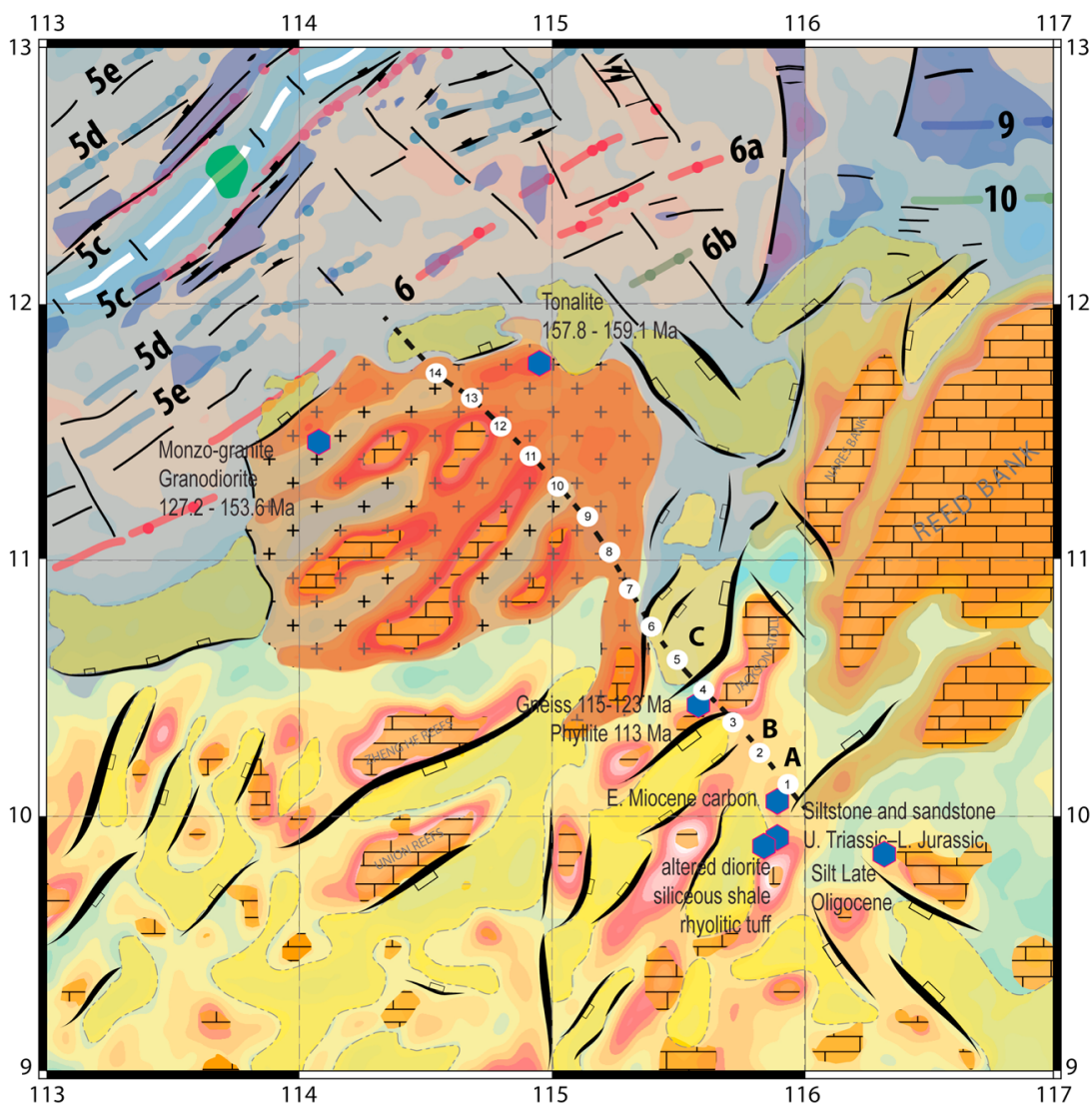

Figure 2. Spratly Islands (Nansha Islands) and Reed Bank area (see black frame in Figure 1 for location). Blue diamonds are dredged rocks in the vicinity of the line. OBS locations are indicated with white circles. Yellow areas are tertiary basins, and orange bricks represent reefal platforms, Brown areas with "cross" signs represent Mesozoic granitoïds. Basins $\mathrm{A}, \mathrm{B}$, and $\mathrm{C}$ visible on Figure 3 are indicated.

seismic section discussed in this paper (Figure 2; Kudrass et al., 1986). Dated paragneiss and schist (104-123 Ma; Kudrass et al., 1986) suggest that the latest thermo-metamorphic event took place in the early Cretaceous, before widespread Paleogene extension. A cortege of volcanic arc granites (monzogranite, tonalite, and diorite) was dredged close to the continent-ocean boundary (30 to $50 \mathrm{~km}$ off our profile) and dated at 127-159 Ma (Yan et al., 2010). This age range exactly coincides with the peak production of Yenshanian granites in South China (Zhou et al., 2006), strongly supporting that the area of Dangerous Ground was part of a larger Mesozoic granitoid belt of subduction encompassing the margins of South China and East Vietnam (Taylor \& Hayes, 1983; Lapierre et al., 1997; see discussion in Breitfeld et al., 2017; Morley, 2012; Pubellier \& Morley, 2014). This belt, produced by the northwestward subduction beneath eastern Asia of one of the plates that formed the paleo-Pacific ocean in Jurassic and Cretaceous (Izanagi plate; e.g., Zahirovic et al., 2014), was active from Middle Jurassic to late Cretaceous, with a sharp decrease of magmatism after $90 \mathrm{Ma}$ (Zhou et al., 2006). The exact shape of this Cretaceous subduction/accretionary boundary is speculative, but may have been close to Dangerous Ground based on the abundance of granitic rocks west of it (Li et al., 2018; Pubellier et al., 2016; Zhou et al., 2008). An important implication is the strong heterogeneity of the Dangerous Ground crust prior to Paleogene extension, both lithological and structural, in the form of tectonic contacts between geological units, rheological boundaries between sediments, metamorphic and granitic bodies, and other mechanical boundaries such as large-scale erosional surfaces or flanks of broad Mesozoic folds (Pubellier et al., 2016; Savva et al., 2014; Yan et al., 2014).

The mean crustal thickness in Dangerous Ground is 15 to $20 \mathrm{~km}$ based on deep seismic, refraction, and gravity inversion (Ding et al., 2013; Gozzard et al., 2018; Peng et al., 2018; Pichot et al., 2014; Wei et al., 2015). The area thus remained remote from the main zones of extreme stretching/necking that led to 
oceanic spreading in the South China Sea basins. North of Dangerous Ground, transition to the oceanic lithosphere of the SW subbasin is rather abrupt (Pichot et al., 2014). South, seismic profiles show tilted blocks beneath the Northwest Borneo Trough facing the Spratly Islands proper and beneath the Reed Bank Basin and West Palawan Basin facing Reed Bank (Cullen, 2010; Ding et al., 2012; Hinz \& Schlüter, 1985; Steuer et al., 2014; Yao et al., 2012). Crustal thickness within these troughs may be as small as 10 km based on gravity modeling and refraction seismic (Franke et al., 2008; Hinz \& Schlüter, 1985; Milsom et al., 1997; Vijayan et al., 2013). Thin crust of presumably continental origin is also found further south beneath the Sarawak margin (Madon et al., 2013). A thin-crust basin thus runs south of Dangerous Ground, with the same trend and possibly the same type of rotated blocks controlling Tertiary sediment fills. Offshore North Palawan, the equivalent of Dangerous Ground is absent and the thick inverted margin there connects to the oceanic crust of the East Basin, with the Northwest Palawan Basin in between (Aurelio et al., 2014; Franke et al., 2011). Further south, most of the south Dangerous Ground thin-crust basin is now buried beneath the allochtonous fold-and-thrust belt offshore Sabah (Franke et al., 2008; Hesse et al., 2009; Schlüter et al., 1996), and the southern margin is either totally lost or present beneath the wedge as crustal salients (Sapin et al., 2011).

Besides being floored with relatively thin crust, Northwest Borneo Trough and Palawan Trench (Figure 1) have been further depressed as flexural moats ahead of advancing allochtonous wedges, as originally proposed by Hinz and Schlüter (1985) (Cullen, 2014; Hutchison \& Vijayan, 2010; Ilao et al., 2018; Madon et al., 2013; Milsom et al., 1997). The carbonates buildups of Dangerous Ground may thus be presently located at the flexural bulge (Hall, 2013; Steuer et al., 2014), and the entire region may have recorded the progression of the nappes.

\section{Data Acquisition and Processing}

The joint Guangzhou Marine Geological Survey/Ecole Normale Supérieure project started in 2011 with the acquisition of a 1,000-km-long refraction line shot using the R/V Tan Bao and 50 ocean bottom seismometers (OBS) deployed across conjugate margins and ocean basin of the South China Sea. In a second phase of the project (2011 to 2013), a 1,000-km-long multichannel seismic (MCS) reflection line-coincident with the refraction seismic line-was shot using the DongFang KanTan and Tan Bao research vessels with an $\sim 7,000$ cu.in. tuned air gun array and 6- to 8-km-long streamers, respectively. Preliminary results of the refraction data set (Figure 1) provided a first estimate of the velocities, crustal thickness, and Moho depth solely from the refraction data (Pichot et al., 2014). The full coincident MCS data set now allows further processing by constraining the basement geometry, a crucial step in refraction modeling that was missing in our preliminary work. We propose here a proper joint interpretation of refraction and reflection profiles of the southernmost portion of the line.

\subsection{Multichannel Seismic Reflection Data Set}

The 230-km-long section of the profile across Spratly Islands processed in this study consists in 4,525, 50-mspaced shots, each of them being recorded on 480 channels with offset ranges from 130 to $6,130 \mathrm{~m}$ (R/V DongFang KanTan). The trace record length is $16 \mathrm{~s}$ two-way travel time (TWT) with a 2-ms sampling rate. The MCS processing workflow has been designed and performed at Ecole Normale Supérieure using the CGG Geovation 2013 software. The strategy of the workflow aims at imaging deep reflectivity by fine-tuning the multiple attenuation procedure when possible. Figure 3 shows $110 \mathrm{~km}$ of the southernmost section of the profile, while Figure S1 shows the remaining $120 \mathrm{~km}$ of the processed section across Spratly Islands to the north (see Figure 1a for location).

The analysis and discussion focus on the area south of Spratly Islands (Nansha block; Figure 3), the section across the Spratly Islands proper being more difficult to process and less promising in terms of deep reflectors (Figure S1). The reason is threefold: (1) shallow seafloor with poor sedimentation and narrow half-graben basins bounded by basement highs makes it difficult to correlate horizons, (2) the shallow basement scatters back the source energy resulting in a lesser penetration of the seismic energy and is further responsible for strong multiples and diffractions that are difficult to remove, and (3) the large number of basement highs related to shallow rooting normal faults tilting blocks induces significant lateral variations of the velocity field (see Figure $4 \mathrm{~b}$ ) leading to difficult time migration of the image there (within a CDP gather, all traces of different incident angles are migrated with a 1-D velocity profile). 
a

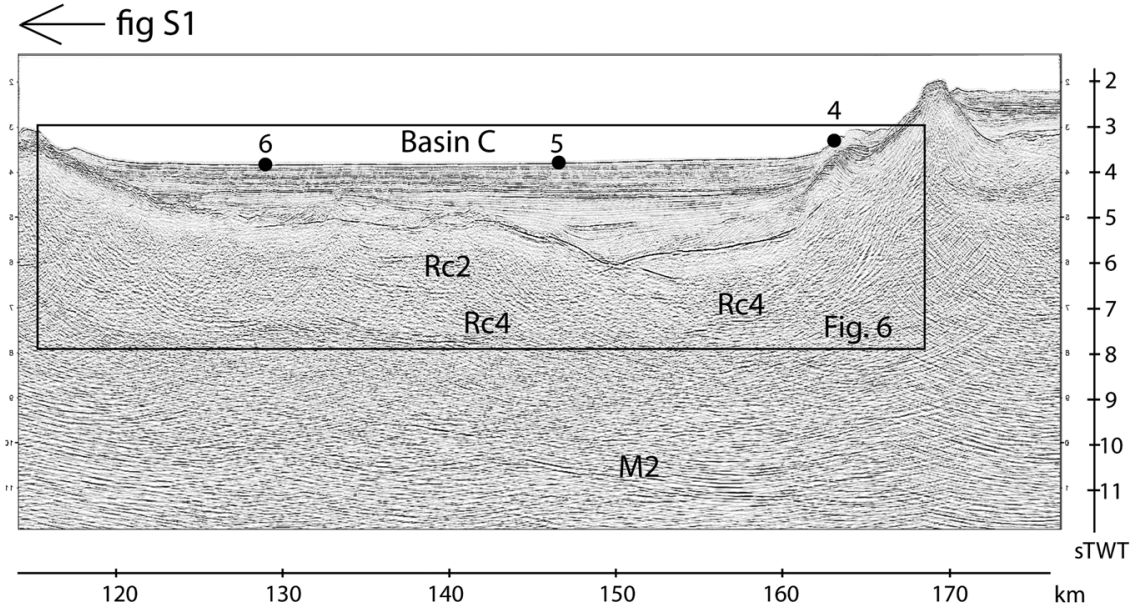

b

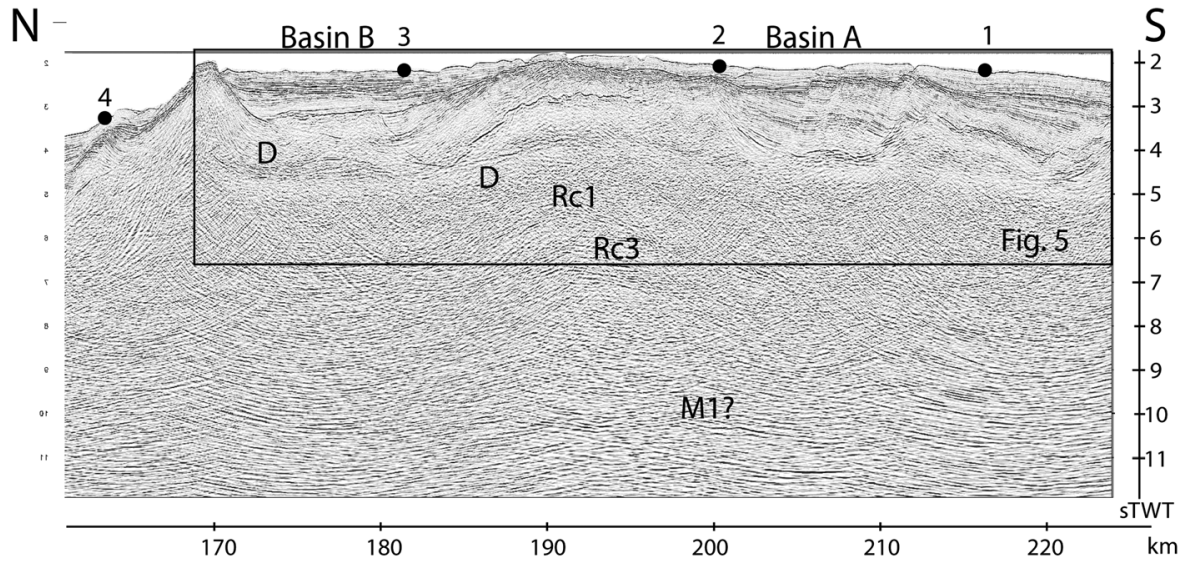

Figure 3. Section of the 230-km-long processed MCS profile from 110 to $225 \mathrm{~km}$ (see location on Figure 1). This section, south of the Spratly Islands (Nansha Islands), is the most sedimented, therefore allowing the imaging of deep reflectivity. The section from 0 to $110 \mathrm{~km}$, more difficult to process (see text), is presented in Figure S1 in the supporting information. Vertical axis shows seconds in two-way travel times (sTWT)

On the contrary, Figure 3 shows that the section from 110 to $225 \mathrm{~km}$ is much more sedimented and includes only one significant basement high ( 165-km marker). Figure $4 \mathrm{~b}$ helps visualizing this contrast of lateral velocity variations between the north and south of the line.

For the section in Figure 3 that is central to our study, the workflow includes geometry, denoising, bin centering, offset regularization, predictive deconvolution, multiple attenuation (SRME, radon, F-K), highdensity velocity analysis, prestack Kirchhoff time migration, and finally amplitude recovery. The resulting image is described in section 4. For the section of the profile in Figure S1 from 0 to $110 \mathrm{~km}$, the workflow is similar but we were not able to recover the deep reflectivity.

\subsection{Refraction Data Set}

Because we now have access to basement geometry and crustal reflections from the MCS data, we reprocessed the 230-km-long southernmost section of the refraction data from Pichot et al. (2014), including OBS 1 to 12 (Figure 2). This refraction section is coincident with the MCS profile presented in Figures 3 and S1 (see also Figure 4). At variance with Pichot et al. who used travel time tomography inversion (Tomo2D), we perform here forward modeling of the sedimentary, crustal, and mantle seismic phases to fully take into account the a priori shallow and deep structures given by the MCS image (Rayinvr, Zelt \& Smith, 1992). The method also has the advantage to allow modeling of the secondary arrivals. As a result, a significant addition to the travel times picked in Pichot et al. (2014) is the inclusion of lower crustal 
$\mathrm{N}$

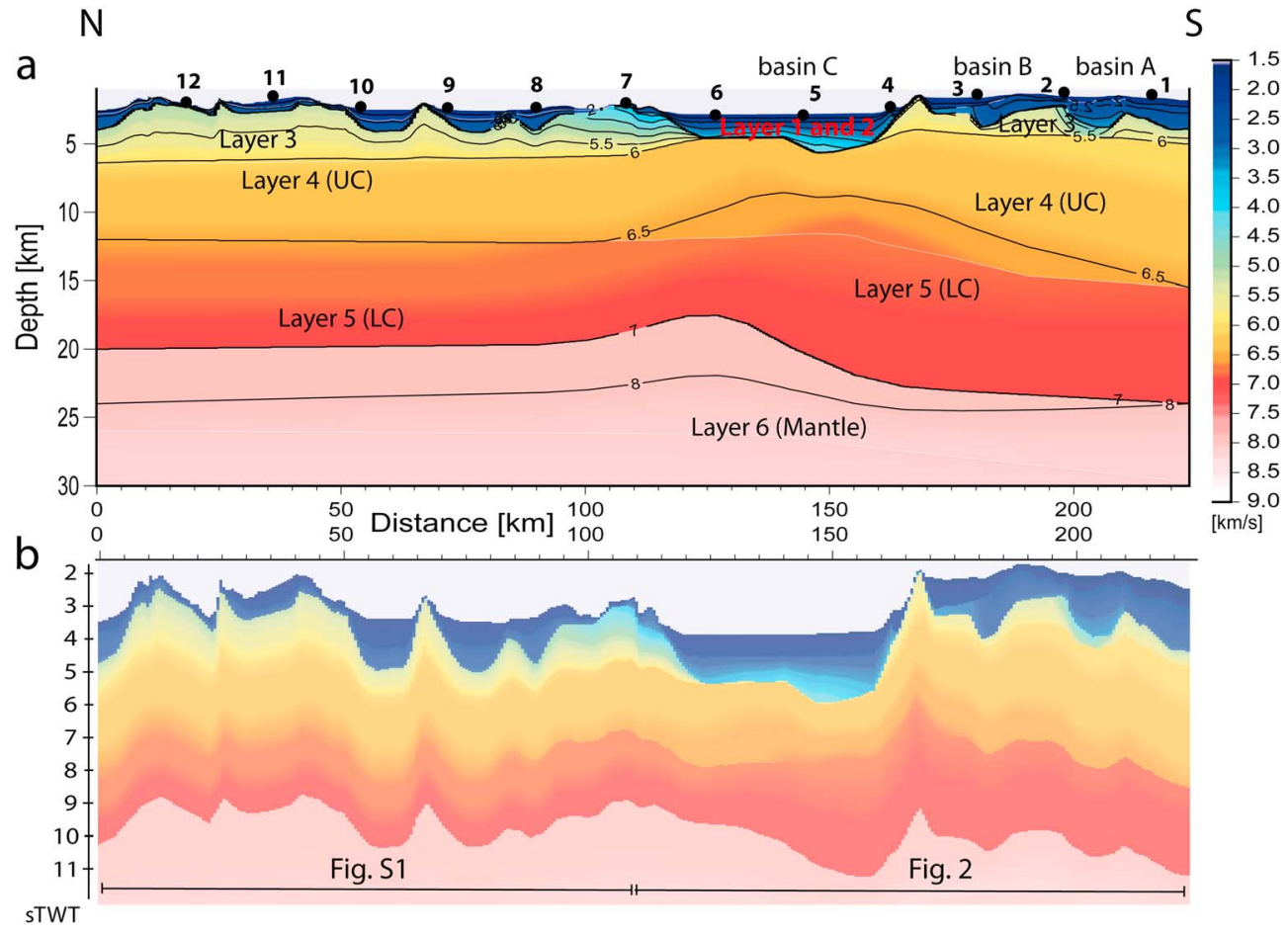

Figure 4. Velocity model obtained by forward modeling. (a) Depth model with OBS number indicated (see positions on Figure 2) and layers (see Table 1). (b) The two-way travel time (TWT) converted model shows strong lateral velocity variations leading to a difficult (1-D) time migration, in particular from 0 to $110 \mathrm{~km}$ (Figure S1).

secondary arrivals that are visible because of the low-velocity gradient of the continental crust in addition to some intracrustal wide-angle reflections. Beyond the additional arrival picks, the many wide-angle reflections in the crust and mantle in some specific areas sometimes made it difficult to accurately interpret the phases (Moho versus deeper mantle reflections versus deep crustal reflections) without the MCS profile. Our MCS processing workflow focusing on deep reflectivity allows us to perform a common interpretation of phases for both independent data sets. The model includes six layers: two layers of tertiary sediments, one layer of metamorphic sediments (subbasement), one upper crustal layer, one lower crustal layer, and the mantle layer. The picked phases associated to each layer are summarized in Table 1. The modeled velocity is shown in Figure 4 and described in section 4. Other details of the

Table 1

Details of the Different Picked Phases, Their Uncertainties, RMS Residuals ( $\left.T_{R M S}\right)$, and Chi-Square Values

\begin{tabular}{|c|c|c|c|c|c|c|}
\hline Phase number & Phase name & Associated layer & Number of picks & Picking uncertainty & $\mathrm{T}_{\mathrm{RMS}}$ & Chi-square \\
\hline 1 & Direct wave & 0 (water) & 580 & 0.015 & 0.014 & 0.915 \\
\hline 2 & Ps1 & 1 (sediments) & 36 & 0.050 & 0.040 & 0.649 \\
\hline 3 & PsP & 1 (sediments) & 325 & 0.080 & 0.099 & 1.530 \\
\hline 4 & Ps2 & 2 (sediments) & 228 & 0.050 & 0.042 & 0.704 \\
\hline 5 & $\mathrm{PbP}$ & 2 (sediments) & 355 & 0.080 & 0.112 & 1.973 \\
\hline 6 & Ps3 & 3 (metamorphic sediments) & 1420 & 0.060 & 0.085 & 2.022 \\
\hline 8 & Pc1 & 4 (upper crust) & 4926 & 0.075 & 0.095 & 1.614 \\
\hline 9 & $\mathrm{PcP}$ & 4 (midcrust) & 1202 & 0.100 & 0.094 & 0.882 \\
\hline 10 & Pc2 & 5 (lower crust) & 2956 & 0.080 & 0.091 & 1.304 \\
\hline 11 & $\mathrm{PmP}$ & 5 (Moho) & 3529 & 0.100 & 0.080 & 0.647 \\
\hline \multirow[t]{2}{*}{12} & Pn & 6 (mantle) & 2017 & 0.100 & 0.109 & 1.194 \\
\hline & Total & & 17719 & & 0.091 & 1.263 \\
\hline
\end{tabular}

Even phase numbers represent refraction phases whereas odd phase numbers are reflection phases. Each phase is associated to a layer number shown in Figure 4. Reflection phases are related to the bottom of the indicated layer. 

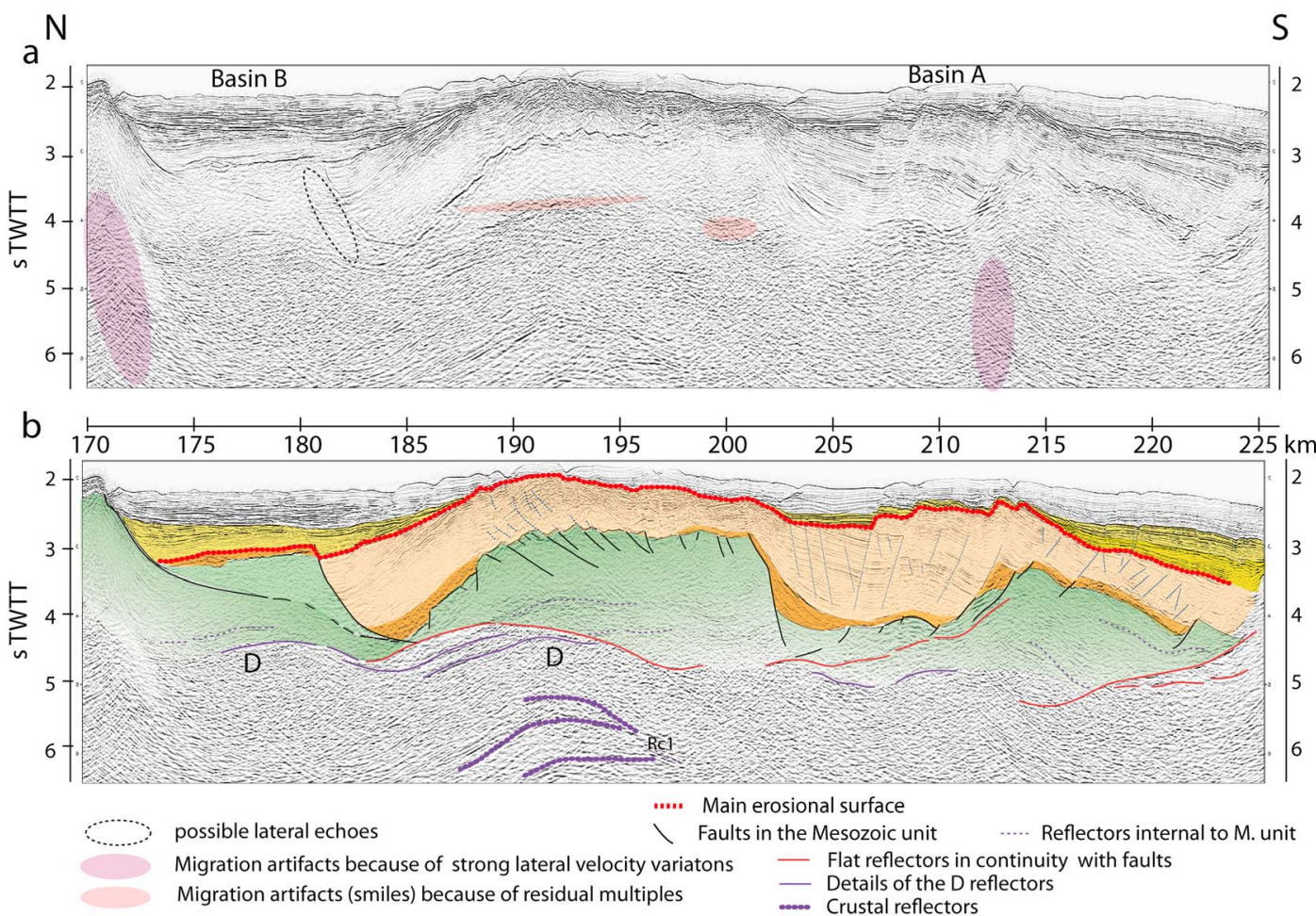

Figure 5. Southernmost section of the profile corresponding to the frame outlined in Figure $3 \mathrm{~b}$ (basins A and B). The images displayed are all prestack time migrated. The images have been cut to 7-s TWTT. (a) Uninterpreted image. The dashed ellipse shows probable lateral echoes that are not possible to properly migrate in 2-D. (b) Interpreted image. Green units are interpreted prerift metamorphic sediments; brown and light orange units are Paleogene basin fill. Yellow units are synrift, most likely Miocene sediments (see text).

refraction modeling strategy and tests of robustness of the model are discussed in the supporting information. In particular, Figure S2 displays the diagonal matrix sensitivity test as well as all picks and modeled arrivals for each OBS and the corresponding ray coverage. Figure S3 displays some robustness analysis where some parameters (velocity or depth nodes) of the model corresponding to key features are varied. Finally, Figure S4 shows all record gathers (hydrophones and vertical geophones) with superimposed picked and synthetic travel times.

\section{Imaging Results}

Several sedimentary basins (Figures 3, 5, and 6, basins A, B, C) and seismic sequence boundaries have been identified. Prerift, synextension, and postrift sediment interpretation is mostly based on seismic characteristics, including reflection frequency, amplitude, continuity, and reflection termination (onlap, downlap, and truncation). For commodity, we divided Figure 3 into two sections: the south of the line with basins A and B and the deeper and wider basin C, separated from A and B by a very narrow basement high immediately north of them. We describe below the main sedimentary units from bottom to top, the crustal reflectivity, and finally detail the coincident refraction velocity model.

\subsection{Sediments and Seismic Sequence Boundaries}

A prerift sedimentary unit (green unit) is identified in basins A and B (Figure 5). Internally, the prerift sedimentary unit is characterized by a rather chaotic facies that would be difficult to differentiate from a crystalline basement if it were not for the presence of sparse and low-amplitude internal reflectors (dashed purple in Figure 5). This layer may represent the old Precambrian basement of the South China block, its Late Proterozoic and Paleozoic cover of mostly Sinian to Devonian clayey and sandy flysch, Devonian quartzite, Carboniferous to Permian limestone, and Triassic sandstone. Atop this unit, a well-expressed acoustic basement shows distributed fault offsets, while subhorizontal wavy (in time domain) reflectors lie at the base of 


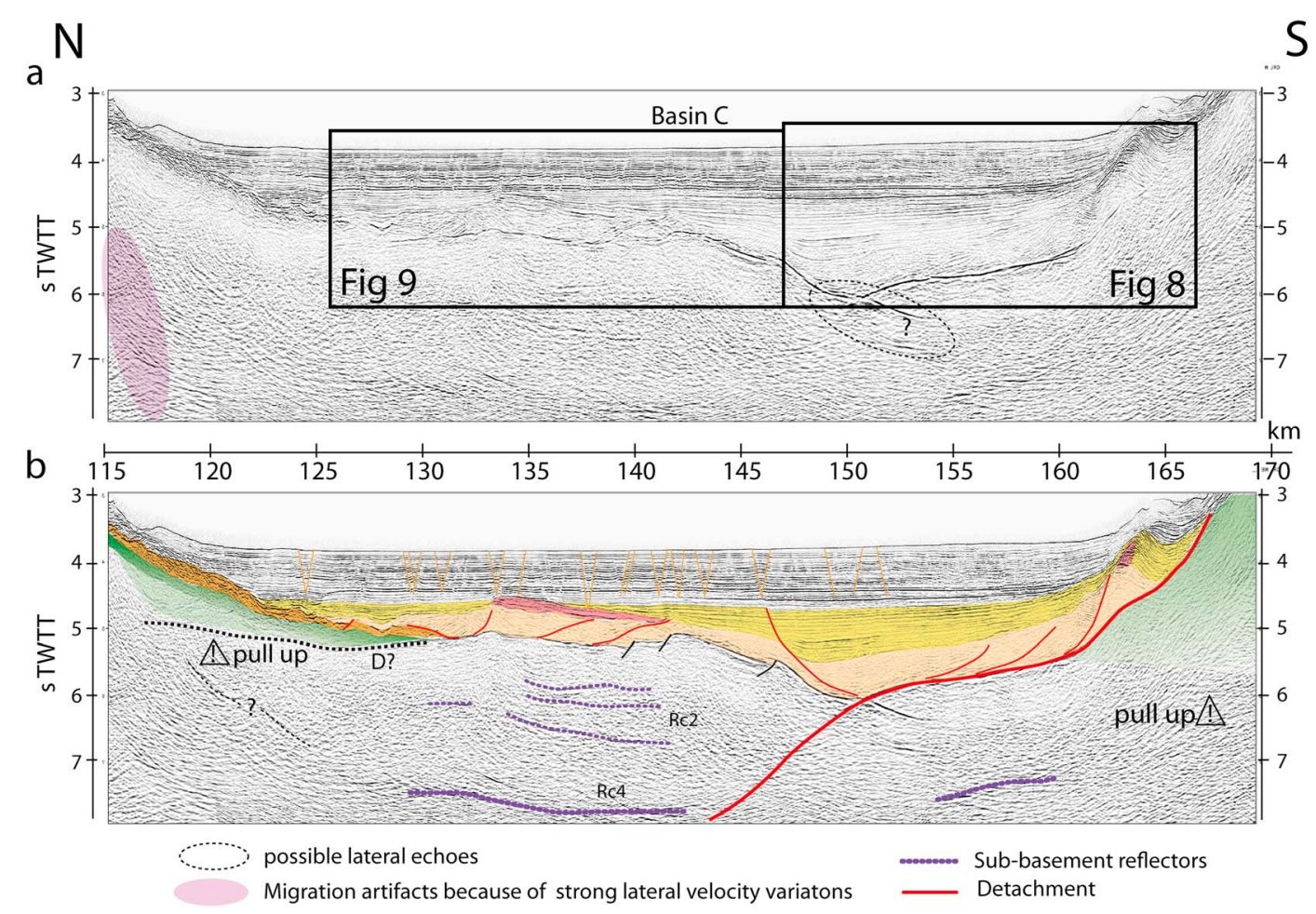

Figure 6. Section of the profile corresponding to the frame outlined in Figure $3 \mathrm{a}$ crossing basin $\mathrm{C}$. The images displayed are all prestack time migrated. The images have been cut to 7-s TWTT. (a) Uninterpreted image with frames locating Figures 8 and 9. (b) Interpreted image. Green units are interpreted prerift metamorphic sediments; brown and light orange units are Paleogene basin fill. Yellow units are synrift, most likely Miocene sediments; purple units are interpreted as carbonate platforms (see text).

the unit. Between markers 185 and 190, the basement and the prerift unit below bend sharply similar to a rollover structure, emphasizing large slip on a low-angle normal fault. At marker 170, the basement crops out at the seafloor. There, Cretaceous paragneiss were dredged (104-123 Ma; Kudrass et al., 1986). We will discuss later the whereabouts of this unit to the north in basin C.

Above the prerift unit lies a sequence (brown units on Figure 5) assumed to correlate with the early basin fill of coarse clastics during the formation of onshore basins from late Cretaceous to late Eocene (Chan et al., 2010). Although this unit generally fills passively the depressions, it sometimes thins laterally indicating local block rotation (Savva et al., 2014). This unit has a rather chaotic to transparent facies with coarse noise.

In all basins, we then observe a stratified unit (light orange) of variable thickness, loosing reflectivity where tilted. Within basins A and B, this unit is affected by numerous and sharp faults, but without clear syntectonic wedges. This would indicate that sedimentation rate was very high and/or extension rates on steep faults were low during deposition.

Above this light orange unit, we observe a strong erosive surface truncating tilted reflectors (best visible on Figure 5 from markers 190 to 215) with a layer of postextension sediments (colorless on Figure 5) sometimes directly lying upon it (markers 190 to 200; Figure 5). On the sides of the rollover structure however, we image a clear synextension sediment unit with a thickness (yellow in Figure 5) decreasing toward the top of blocks bounded by faults, although sedimentary wedges are not extremely developed. In some places, we identify two unconformities and onlaps in the synrift sediments, in accordance with descriptions of the synrift packages observed in other locations in the SCS (e.g., Ding et al., 2012; Franke et al., 2014). The continuity of the previously described erosive surface can be followed within the yellow synextension layers, showing that this phase of extension on shallow rooting normal faults took place under very shallow water level.

To the north, in basin C (Figure 6), a similar wedge-shaped synextension layer is also observed, possibly bounded by two coral reefal structures (light purple in figure 6). Thin in basins A and B, postrift 
sediments are thicker in basin C. They show internal parallel-layered reflectors with highly continuous signal. The postrift sediments are mostly undeformed, except for numerous shallow rooted compaction faults. Below the yellow synextension unit in basin C (Figure 6), we identify a unit showing chaotic signals typical of sediments having experienced gravity collapse or sliding. From the position of the unit between the basement and the synextension yellow unit, we identify it as being similar to the light orange unit in basins A and B (Figure 5).

\subsection{Crustal and Mantle Reflectivity}

In Figure 3, we indicate the main subbasement reflectors. Reflector D actually represents a thick strip of reflectors interpreted as a shallow décollement—a subhorizontal low-friction surface-where listric faults bounding the above described rollover structure root. Figure 5 shows a more detailed image of the reflectors being a part of this shallow décollement below the green metamorphic sedimentary units. We will discuss in the next section what this décollement becomes in basin C. Deeper in the crust, intracrustal reflectors are labeled Rc1, Rc2, Rc3, and Rc4. Odd Rc numbers correspond to reflectors below basins A and B while reflectors with even Rc numbers are found below basin C. In the following, the second (s) unit stands for two-way travel times. Rc1 reflectors are found $\sim 1-2 \mathrm{~s}$ below décollement $\mathrm{D}$ while Rc2 reflectors are found $\sim 1-2 \mathrm{~s}$ below the acoustic basement of basin C (Figure 3, zooms on Figures 5 and 6). Rc1 reflectors are a clear indication of the sedimentary nature of at least some part of the local continental crust. The many reflectors, although with low signal-to-noise ratio, appear subparallel and sometimes tilted. Rc3 is the next reflector being imaged at $\sim 3 \mathrm{~s}$ below décollement $\mathrm{D}$ (1-s TWT below Rc1; Figure 3) while Rc4 is found at an equivalent $\sim 2-3 \mathrm{~s}$ below the acoustic basement of basin C (1 s below Rc2; Figures 3 and 6). Finally, weak reflectors M1 and M2 are found around 9 to 11-s TWT corresponding to Moho depths.

Reflectors D and Rc4 are close to the seafloor first multiple. Indeed, Figure 5 shows that some multiple residuals, although weak, are still sometimes visible just above reflector $\mathrm{D}$. These artifacts have the particularity to be overmigrated (migration smiles). We see that the shape of the several reflectors below the artifacts correspond neither to the geometry of the seafloor nor to the shallow post rift sediments. Besides, D reflectors are well migrated and form a complex pattern of sigmoid-shaped geometries. For reflectors D and Rc4, prestack data displayed on, respectively, Figures S5 and S6 show that the reflection events have a very different moveout in CDP gathers when compared to the seafloor multiples. Reflector D and Rc4 stack at a much higher velocity and are visible at a large range of offsets in CDP gathers. The geometry of Rc4 is also not perfectly flat, which is yet the case of the seafloor. We conclude that the crustal reflectivity is real and we will discuss it jointly with the refraction velocity image.

\subsection{Structure of the Refraction Velocity Field}

In Figure 4a, the geometries of the two sedimentary layers down to basement with velocities from 1.5 to 3.5 $\mathrm{km} / \mathrm{s}$ are entirely defined from the coincident reflection seismic profile (see Figures 5 and 6). The lateral variations of the velocity within these sedimentary layers, however, are interpolated between the sparse OBS receivers (18-km spacing). As a result, the velocity structure in the sediments does not always exactly follow the reflectivity (i.e., in basin C), by lack of resolution. This sediment velocity and more importantly the basement geometry are however crucial to properly model the deeper layers.

Layer 3 in Figure 4a, below tertiary sediments, lies between the acoustic basement and the approximate depth of the décollement $\mathrm{D}$. The velocity ranges from 3.5 to $5.5 \mathrm{~km} / \mathrm{s}$. The $5-\mathrm{km} / \mathrm{s}$ velocity at the outcropping basement around marker 170 (Figure 4) corresponds to the location of the dredged Cretaceous paragneiss. As the velocity is similar below the rollover structure basement, this was another reason to draw the green layer as we did in Figure 5. The bottom geometry of this layer 3 is mainly inspired by the presence of the D reflectors in the reflection image. However, the velocity contrast between Tertiary sediments and upper crust clearly appears milder in basin $\mathrm{A} / \mathrm{B}$ when compared to basin $\mathrm{C}$, where there is a direct contact between $3.5-\mathrm{km} / \mathrm{s}$ Tertiary sediments and an $\sim 6.2-6.35-\mathrm{km} / \mathrm{s}$ basement (Figure 4 ). In basin C, we find no velocity corresponding to the green metamorphic unit visible in basin A/B. The large basement velocity contrast in basin $\mathrm{C}$ is in excellent agreement with the very high amplitude of the basement reflector there (Figure 6). Layer 3 is again necessary to properly model refraction arrivals north of basin C (Figures 4 and S1), across Spratly Islands (Nansha Islands). The thickness and velocities there are very comparable to the equivalent layer modeled by Lü et al. (2016) in the Zhongjian Massif, conjugate of Spratly Islands (Nansha Islands). 


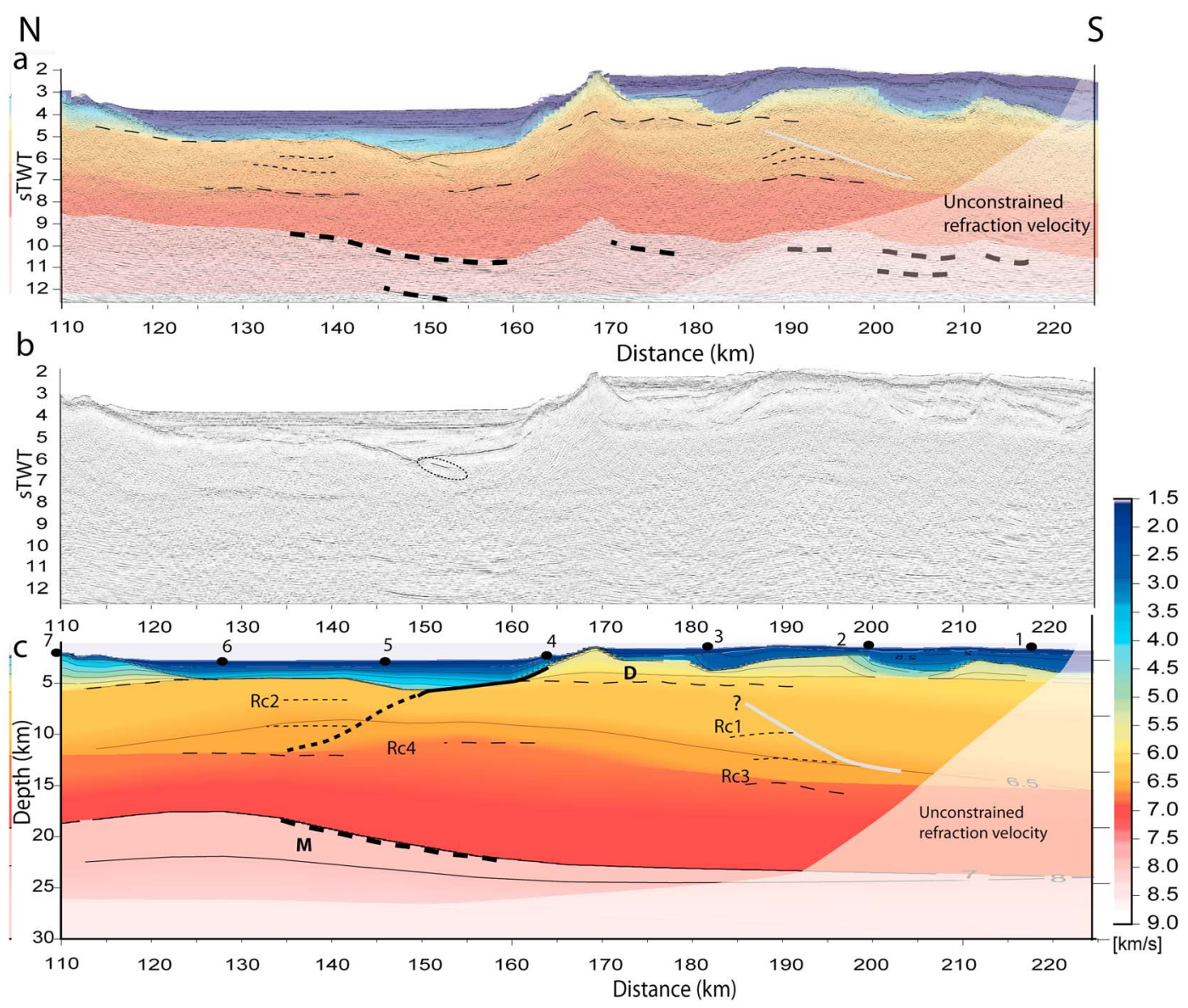

Figure 7. (a) Time converted refraction velocity model superimposed on the time migrated reflection seismic section. Black dashed lines are crustal reflectors seen in (b) the uninterpreted time domain MCS image. Thick black lines are potential faults after interpretation of the position of the reflectors in (c) the depth domain velocity model. The dashed ellipse indicates a migration artifact.

Velocities higher than $6 \mathrm{~km} / \mathrm{s}$ correspond to the modeled top of the upper crustal layer, both beneath the Tertiary sediments of basin $\mathrm{C}$ and beneath $\mathrm{D}$ reflectors. The top upper crustal velocity decreases slightly to $6.1 \mathrm{~km} / \mathrm{s}$ away from its maximum in basin $\mathrm{C}$ area. The base of the upper crust corresponds to some wide-angle intracrustal reflections in the OBS data. However, as in the reflection profile, the refraction data exhibit multiple, unclear crustal reflectors forming bands of reflectivity similar to the Rc3 series (Figure 3). This is the case even further to the north of the Rc3 zone where the reflection image does not show anything clear because the basement high (marker 170; Figure 3) prevents a good imaging of the crust. Consequently, it is difficult to identify a single clear reflector for the base of upper crust in the refraction data. The overall velocity of the crust (including lower and upper layers) is the only robust feature to interpret, not the thickness of the modeled layers that are used solely for construction of the best fitting model with two linear gradients.

The rationale for dividing crustal layers into upper and lower is still that the upper crustal layer has a higher velocity gradient than the lower crustal layer, especially below basin C with $0.08 \mathrm{~s}^{-1}$ for the upper crust to be compared with $0.02 \mathrm{~s}^{-1}$ in the lower crust below. The lower crustal velocity and velocity gradient are especially well constrained by a very long offset secondary arrival phase typical of continental lower crust (Pc2; Figure S4). The top and bottom velocities of the lower crustal layer are, respectively, $6.5-6.8$ and $7.0 \mathrm{~km} / \mathrm{s}$ and are very stable laterally.

Finally, the Moho geometry (or base of the lower crustal layer) is well constrained by many PmP wide-angle reflections that coincide well with the Moho visible in the reflection profile (see Figure 7), especially its 5-km uplift below basin C. The Moho is rather flat elsewhere. 


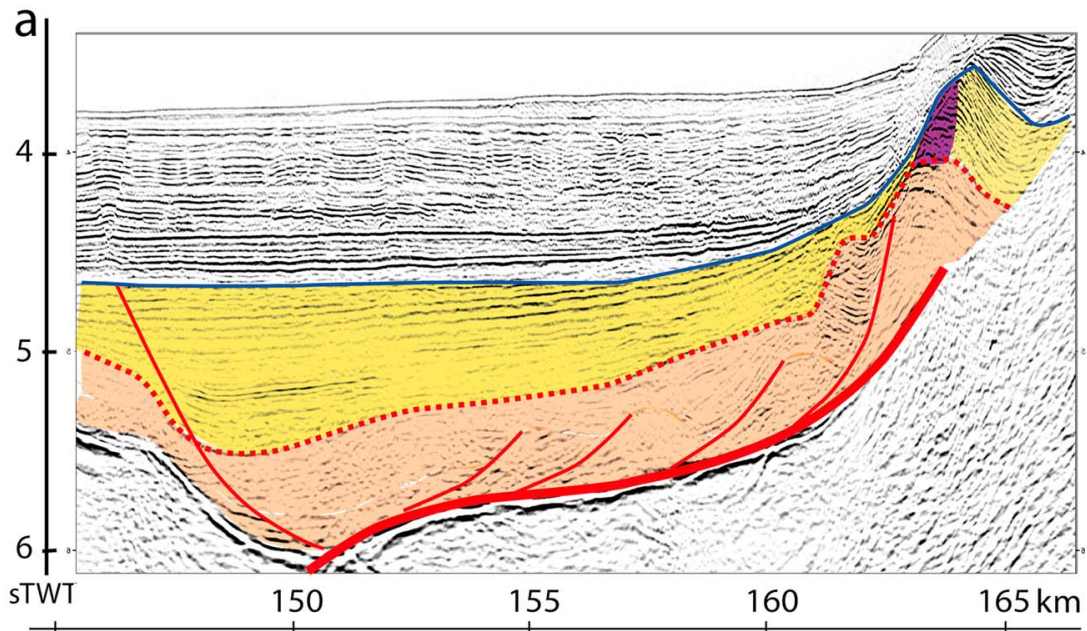

b

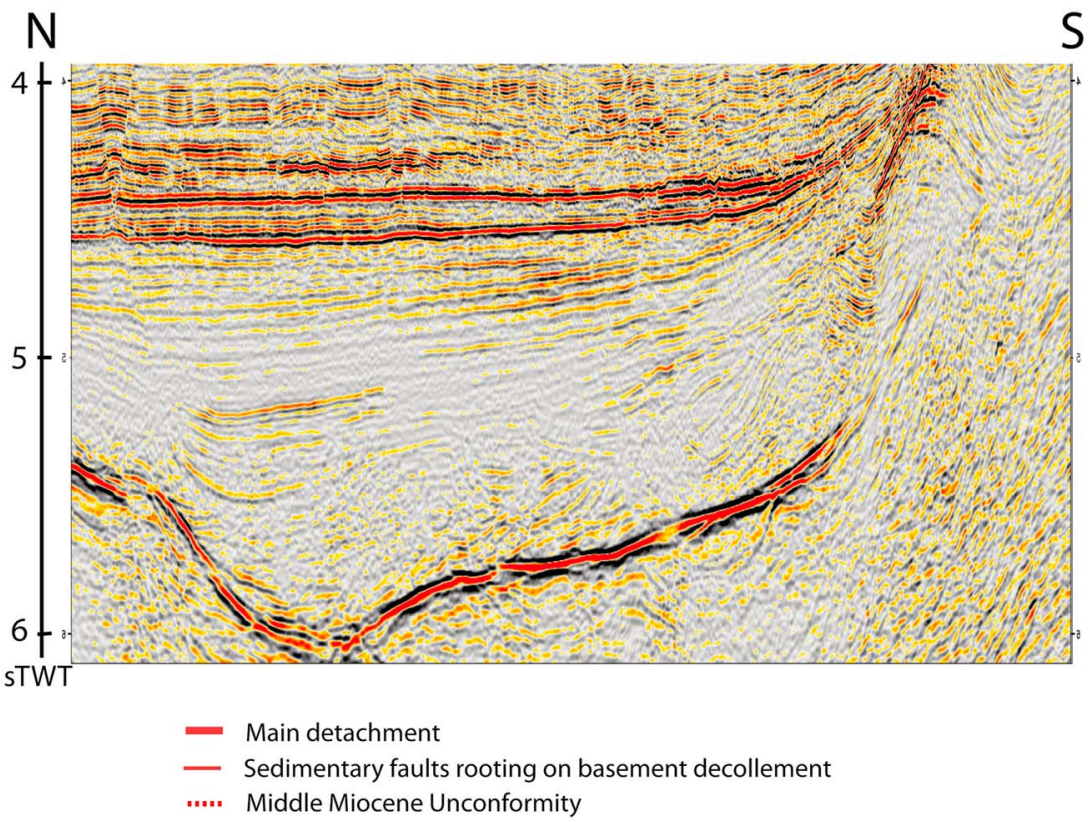

Figure 8. Blow-up image of the south of basin C (see Figure 6 for location). Two different images are presented. (a) The interpreted image is the same processing than Figure 6. (b) The bottom image is also obtained with the processing of Figure 6, but with a different color scale highlighting amplitude contrasts. Purple unit corresponds to interpreted carbonates built between the mid Miocene unconformity (breakup unconformity) and the end of extension (blue horizon). Yellow unit is interpreted as a Miocene unit while the collapsed light orange unit above basement is Eocene (see text and Figure 10).

\section{Discussion}

\subsection{Formation of Basin $\mathrm{C}$ and Sedimentation}

Below basin $\mathrm{C}$, crust has thinned from 20 to less than $15 \mathrm{~km}$ over a distance of about $50 \mathrm{~km}$. A mantle dome is located off the main axis of the basin (Figure 7c). To explain the presence and location of the dome, a north verging detachment—a long-lived, low-angle normal fault—is the most obvious (Wernicke, 1985). This large crustal detachment controlling the formation of basin $\mathrm{C}$ is the dominant feature of this key section of the SCS (Figure 7c). Figure 8 shows a zoomed image of the flat footwall of the detachment and sedimentation above, while Figure 9 shows the hanging wall block surface. The detachment clearly controls the tilt and slide of large blocks of upper crust. We can infer that if a basin was filled by sediments before the main activity of the detachment, this basin would collapse because of the space created by the apparent $15-\mathrm{km}$ 
a

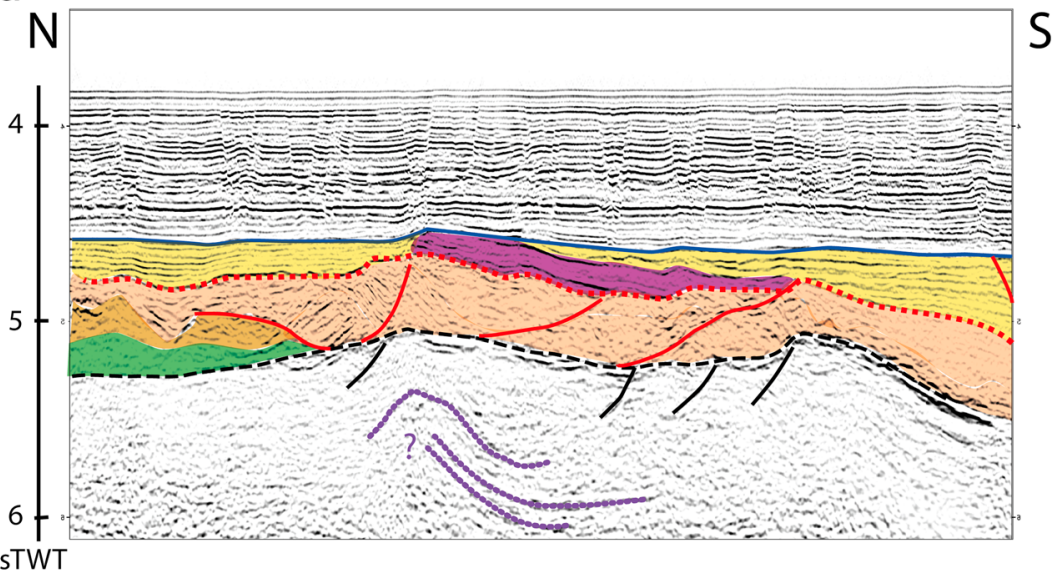
sTWT

b
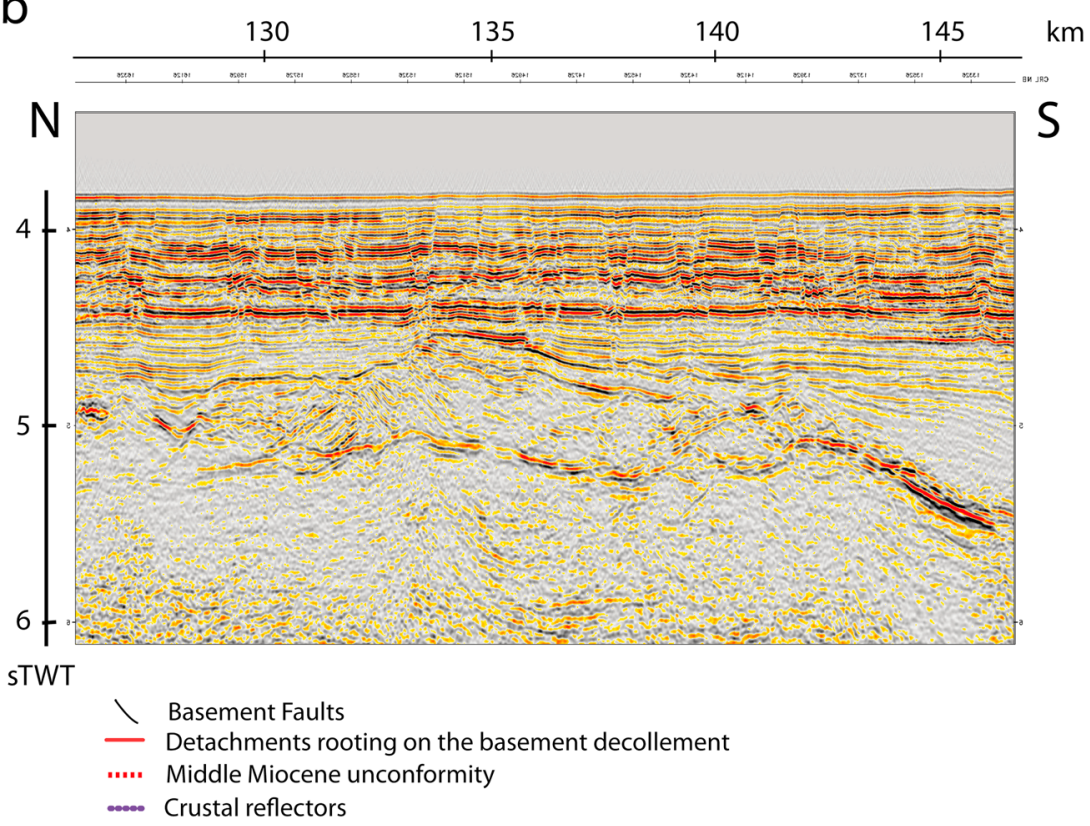

Figure 9. Blow-up image of the north of basin C. Two different images are presented. (a) The interpreted image (top) is the same image than Figure 6. (b) The bottom image is obtained with the processing of Figure 6, but with another color scale highlighting amplitude contrasts differently. Thick dashed black lines represent a décollement level above the hanging wall basement surface. It is continuous with décollement north of basin C (see Figure 6 and 7). The images show interesting "dome-like" structure below the basement that could be the lateral echoes from a volcano. The feature is located beneath the interpreted carbonate platform (purple) that built between the MMU and the end of extension (blue horizon).

detachment heave (Figure 6). The basement-sediment interface was indeed destabilized by the tilting, thus resulting in secondary and shallow sedimentary detachments rooting on the basement surface (Figure 8) or mass transport deposits (MTD).

Although the interpretation of the collapsed units is not easy because of the 3-D nature of the events, the aspect of the seismic packages still shows coherency at places and appears to be clear-cut (Figures 7 and 8) at their base on the detachment and on the décollement above the hanging wall (dashed surface on Figure 8). We therefore favor the interpretation of early syntectonic sediments left-behind during the activity of the large offset detachment.

Above these slided units, large or tiny localized wedges (yellow units in Figures 7 and 8) show a more recent activity in basin C. This last event may be correlated to the final stages of the extension during the sea floor spreading of the SWSB from Early Miocene to late Middle Miocene. This late extension does not seem to be 
accommodated along the main north dipping detachment. Instead, we observe a southward verging shallow fault rooting on the exposed footwall of the detachment (Figure 8).

\subsection{Structural Contrast Between Basins A/B and C}

The geometry of deformation within basins A and B can be entirely explained with faults rooting in a shallow décollement (D), although it is possible that the main rollover bounding fault forming basin B could in fact initially root deeper in the Rc1 reflectors structure (grey fault in Figure 7c). In basin C however, except for the latest phase where small offsets sedimentary faults root in the exposed footwall décollement at the base of the collapsed units (Figure 8), most if not all of the extension was taken onto the deep rooting detachment fault, explaining the size and depth of basin $\mathrm{C}$ itself.

Another difference between basin A/B and basin $\mathrm{C}$ is the apparent absence of the metamorphic sedimentary unit (green unit; Figures 5 and 6) in basin C. This interpretation mainly results from the observation of a high refraction velocity of the footwall and hanging wall basements in basin C $(6.2-6.35 \mathrm{~km} / \mathrm{s})$ when compared to the basement of basins A/B (around $5 \mathrm{~km} / \mathrm{s}$; Figures 4 and 7). This high velocity in basin C compares well with velocities just below the décollement $\mathrm{D}$ of basins $\mathrm{A}$ and $\mathrm{B}$, suggesting that the only difference is the missing layer 3. Based on velocities (Figures 4 and 7), we infer that what we interpret as a metamorphic unit re-appears north of basin $\mathrm{C}$ in a southward tilted basin (Figure 5).

An inherited contact between the upper crust (Paleozoic sediments and crystalline rocks) and Mesozoic sediments could explain the absence of the green metamorphic sedimentary unit in basin C. A possible candidate could be a former thrust active at the time of formation of the Yanshanian belt (Faure et al., 2012; see a simplified sketch in Figure 10, phase 0). Dredged Cretaceous metamorphic rocks (paragneiss and phyllites) point to a burial depth of $\sim 20 \mathrm{~km}$ at the footwall side of the present-day detachment (Kudrass et al., 1986), which is another indication for erosion related to orogeny that could have scalped the Mesozoic sediments in basin $\mathrm{C}$ before the activity of the detachment. This basin $\mathrm{C}$ detachment would then correspond to the reactivation of an inherited, low-angle contact (Figure 10, phase 0), explaining the absence of the green unit today (Figures 6 and 7) and the oblique orientation of the basin (Figure 2).

Basin A is a graben filled with a thin synextension brown unit and a thick light orange sedimentary unit that does not show any clear onlap or wedge (Figure 5). We observe that this same light orange unit filled a "proto basin C" before the main activity of the detachment in basin C (Figure 10) that triggered the collapse of these sediments. This suggests a first phase of deformation in all basins before the detachment really fully reactivates the inherited contact (Figure 10).

\subsection{Phases of Deformation and Relative Chronology}

The images presented herein suggest the succession of at least two main extensional phases. A very early phase of deformation is responsible for the distributed small offset basement faulting in basin A/B and also possibly C (small densely spaced black faults in Figures 5, 6, and 10). The deformation then develops with the dismantling of the green metamorphic sedimentary unit by mostly steep faults creating proto basins A/B (Figure 10, step 1). Initially, only a coarse sedimentation from the erosion of faulted metamorphic units and other basement highs fills the basins (brown units) with a very low sedimentation rate. This is to be compared with the molasse basins of the south margin of China (Chan et al., 2010; Savva et al., 2014). This early phase ends with the steep fault bounded basins being filled with the light orange sedimentary unit (Figure 9, step 2). This unit was also probably deposited in a small proto-basin $\mathrm{C}$.

Although the light orange unit shows tilted reflectors, the reflectors are not showing clear syntectonic wedges. We suggest two hypotheses regarding the deposition of this unit: either (1) low extension rate and high sedimentation rate were accommodated onto nonrotating steep faults or (2) there was really no fault activity in basins A/B. In Figure 10, step 2, at variance with many studies in the area (e.g., Ding et al., 2013; Peng et al., 2018; Song \& Li, 2015), we do not interpret the sedimentary unit just above the acoustic basement $\left(T_{g}\right)$ in basins A/B as the main synrift, as already suggested by Wang et al. (2016).

Because we know that the detachment will accommodate a lot of extension later and the green Mesozoic unit still need to undergo boudinage, the observed properties of the light orange unit in basins A/B imply a multiphase extension or only a temporary local gap of extension, possibly under the effect of nearby 


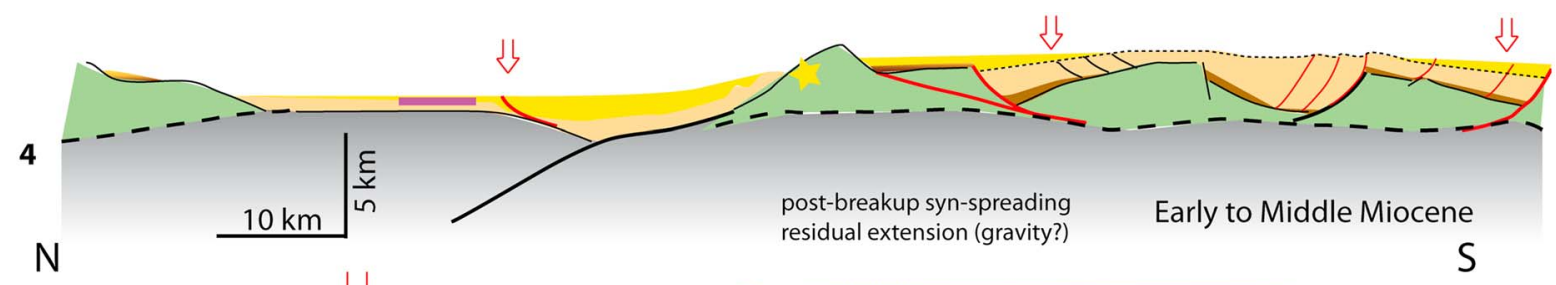

3b

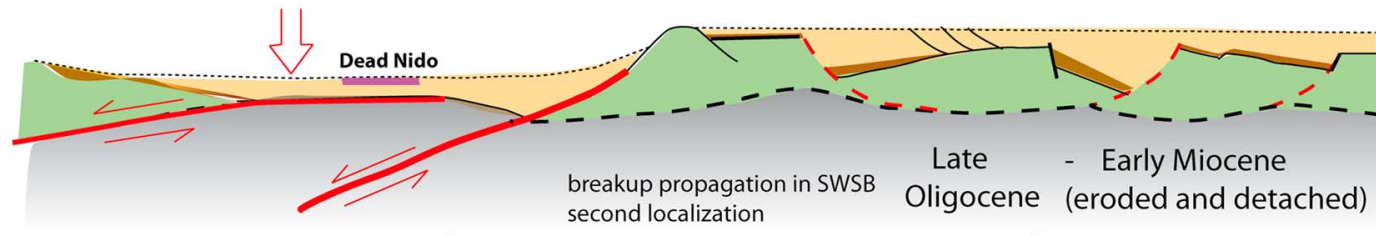

N

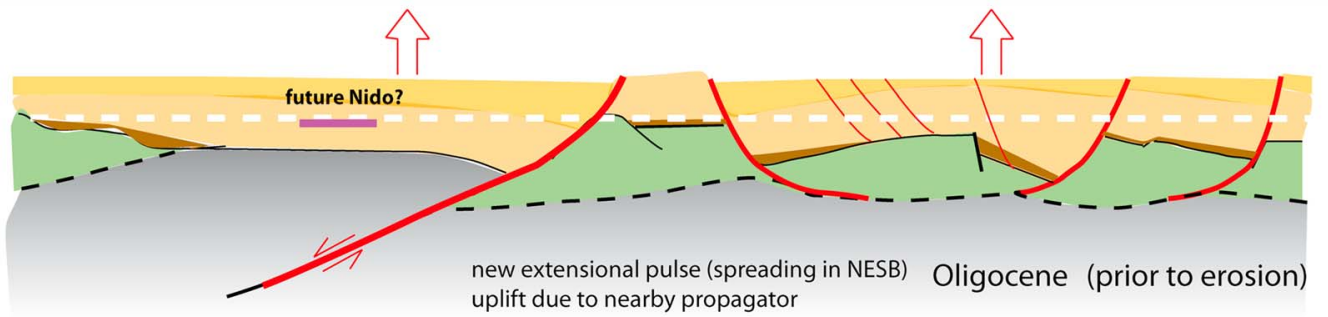

N uplift due to nearby propagator

$3 a$
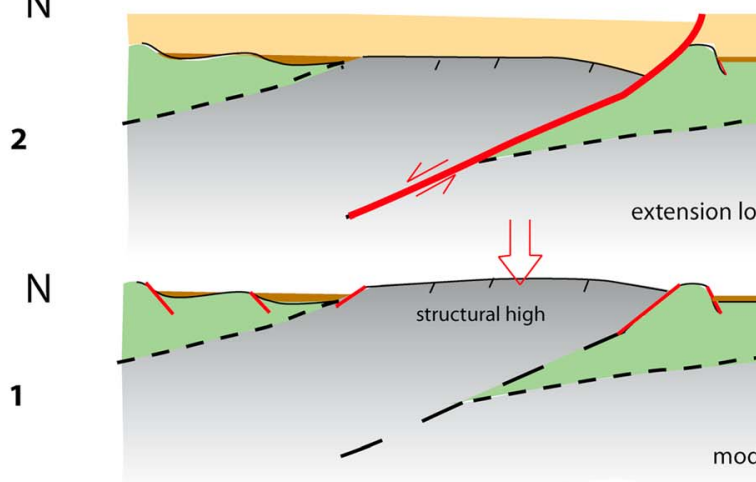

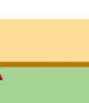

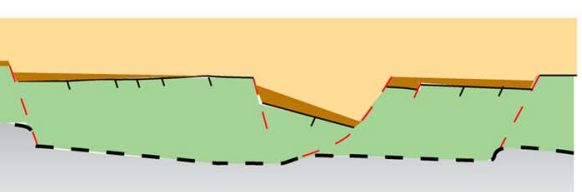

extension localizes on the inherited structure Late Eocene
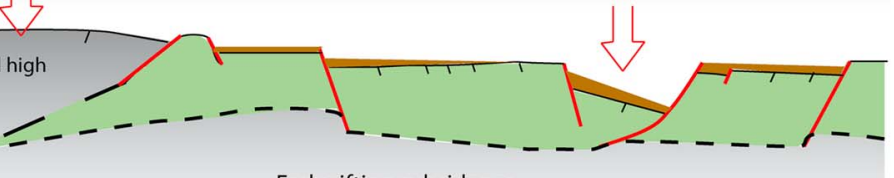

Early rifting subsidence

moderate, distributed extension

Eocene

\section{S}

S

N

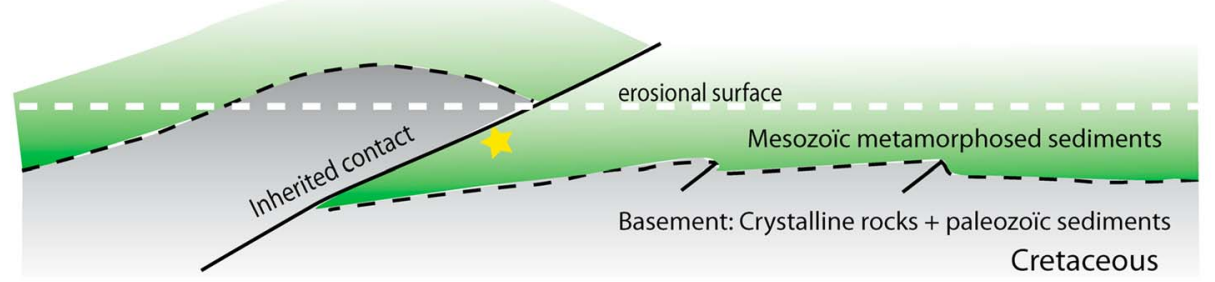

S

Figure 10. Sketch of the main phases of extensional deformation since Cretaceous. The yellow star represents dredged paragneiss (Kudrass et al., 1986) indicating a 20-km depth burial $\sim 120 \mathrm{Myr}$ ago. Colors correspond to units interpreted in the seismic profile in Figures 6, 8, and 9. Red faults represent activity of the faults at the indicated age. Dashed red faults are abandoned faults after localization of extension on the detachment (see text). Ages are suggestions discussed in the text. Red arrows indicate vertical motions.

localization. We favor the second solution with an abandonment of basins A/B fault activity because of the nearby localization of extension on the detachment in basin $\mathrm{C}$. In this situation, the light orange unit fill is synextension in basin C, but not in basin A/B (Figure 10, phase 2). Of course we have no evidence for the synextension nature of the light orange unit in basin $\mathrm{C}$ because the unit later collapses there, erasing the information.

The erosional surface (dashed red, Figure 5) truncates the tilted subparallel reflectors of the light orange unit on both sides of the rollover structure (see Figure 5). This indicates that the bounding listric faults observed today tilted basins A and B before uplift and erosion. Step 3a of Figure 10 illustrates this phase of significant 


\section{a. Main detachment rooting on Mid-crustal décollement, pure shear in lower crust}

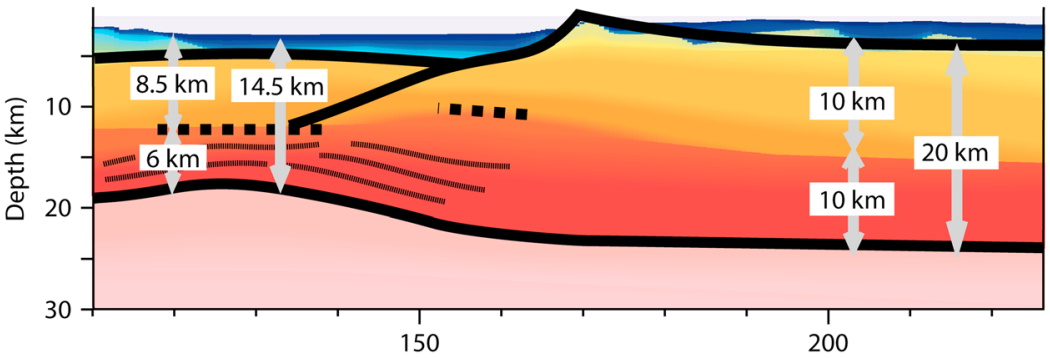

b. Main detachment offsets mid crustal reflector

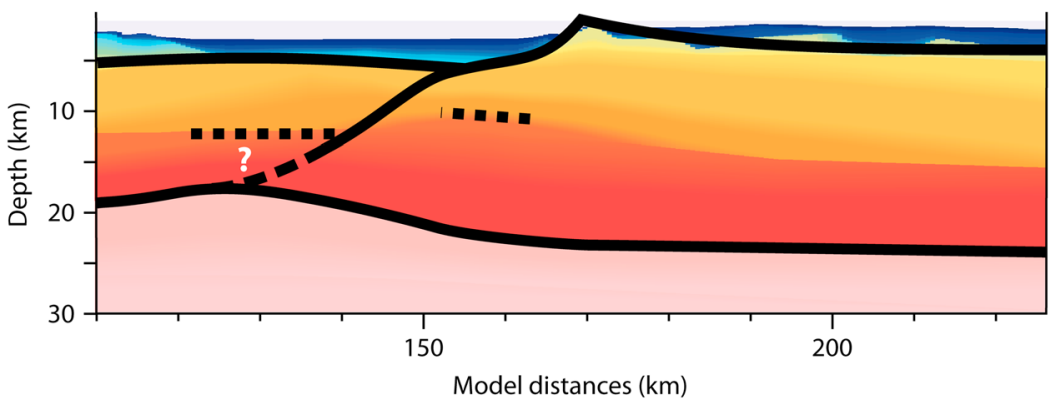

Figure 11. Sketch of the main detachment with possible upper and lower crustal thicknesses. (a) Favored model where the detachment is limited to the brittle upper crust and pure shear occurs in the lower crust. (b) Model with a mostly brittle crust and a detachment offsetting the midcrustal reflector (thick dashed black).

boudinage of the Mesozoic unit above décollement $\mathrm{D}$. Our section shows no syntectonic record of this phase. We suggest that the synrift unit corresponding to this step has been eroded (Figure 10, step 3a to $3 b$ ). The corresponding synrift may however be preserved southwest of our line, where basins A and B seem to be better developed (Figure 2).

The crustal-scale detachment that led to the formation of basin $\mathrm{C}$ accommodated $\sim 15 \mathrm{~km}$ of horizontal extension (Figures 5 and 6). Syntectonic wedged sediments are absent, as expected along a flat (or low-angle) detachment surface. The fact that what appears to be the main rifting phase is finally poorly recorded in the sedimentation record may indicate a short-lived event.

MTDs observed above the detachment surface are most probably composed of sediments deposited during step 2 (Figure 10). An unconformity (dashed red in Figures 8 and 9) and possible carbonates (purple in Figures 8 and 9) also tops the MTDs. Basin $\mathrm{C}$ being located less than $20 \mathrm{~km}$ north of basin B, we infer that the unconformity in $\mathrm{C}$ is coeval with the erosional event in basins A and B. As we observe the unconformity on average 2-s TWT deeper in basin C today and the burial of the carbonate platform above the relatively thin MTD unit, we conclude that the main detachment activity constitutes a step that postdates step 3a, although an overlap cannot be excluded (see step $3 b$ of Figure 10).

The synextension wedges visible today (yellow unit; Figures 5, 6, 8, and 9) do not seem to have recorded any of the extension we described until now, explaining why they are not well developed. In basins A and B, the extension recorded in the yellow unit is a rather minor continuation of the rollover tilt of step 3 (see Figure 10, step 4) in shallow water conditions. This extension on the bounding listric faults explains the tilt of the erosional surface observed today (Figure 10, step 4). South of the profile in basin A, shallow faults in the sediments also offset the erosional surface (Figures 5 and 10) but overall do not account for significant finite extension. In basin C, the latest phase of extension (yellow units; Figure 10, step 4) is also a small sag-type gentle tilt. We suggest that it is quite the same in basins A and B, where this last phase of extension looks more significant but could just be the result of the presence of the weak shallow décollement $\mathrm{D}$ amplifying final gravity adjustments. Interpreting in too much details recent unconformities as phases of extension in the SCS may be an overinterpretation of very local final adjustments, when actually the really large extension phase is older and barely recorded in sediments. 


\subsection{Deep Structures and Processes Around the Detachment}

A single detachment fault can potentially explain the mantle dome, the lower crustal thickening, and the surface geometries. The deep fault geometry is however not imaged directly and can be inferred only from the sparse deep reflectors. Reflector Rc4, in particular, is strong in amplitude and is imaged on the footwall side (S) $2 \mathrm{~km}$ shallower than on the hanging wall side (N; Figure 7). In both locations it matches quite well the boundary between upper and lower crusts in the refraction velocity model. It could be reasonable to infer that the detachment fault locates in between the two Rc4 reflectors (Figure 11b) to offset them. This first hypothesis also implies that the Rc4 reflectors do not correspond to a décollement level and that the lower crust is not likely to be ductile. The reflectors are then probably inherited from pre-Tertiary events. However, the limited 2-km offset between the south and north Rc4 branches is too small compared to the $15-\mathrm{km}$ surface offset of the detachment (Figure 11b), unless they were first thrust-offset before extension. Besides, in order not to cross the hanging wall-side Rc4 reflector $(\mathrm{N})$, the detachment fault would have to down bend to a $40^{\circ}$ dip angle, which may be a bit too steep for a reactivated thrust structure (Figure 11b).

Another possibility is to consider a detachment limited to the upper crust and rooting at the top of the lower crust on a shear zone that could be Rc4 itself. In this case a lower angle of $25-30^{\circ}$ would be maintained along the crustal detachment (Figure 11a). Rc4 reflectors would be indicative of ductile flow in the lower crust (Figure 11a), unless solely the midcrust was ductile (Mohn et al., 2012; Péron-Pinvidic \& Manatschal, 2008). We however favor interpretations including a warm, fully ductile lower crust (Clerc et al., 2017), as it is commonly accepted in the South China Sea. The SCS has many properties of a type II margin in the sense of Huismans and Beaumont (2011) with for instance a limited synrift subsidence that may be due to mantle breakup preceding crustal breakup. In this situation, it seems natural to observe a mantle dome and favor the classic pure shear in the ductile lower crust and simple shear in the upper crust with a detachment rooting at the base of the brittle upper crust (Figure 11a; Wernicke, 1985; Weissel \& Karner, 1989).

If basin $\mathrm{C}$ crustal detachment gives good insight on how extension is accommodated at depth around the detachment, we do not image any obvious structures related to extensional process deep below basins A and $\mathrm{B}$, perhaps because of less favorable acoustic conditions (basement of basins A and B is shallower than basin $\mathrm{C}$ basement, with more basement geometry lateral variations, poor refraction ray coverage at the edge of the profile). Another hypothesis is that once extension localized on the main detachment, other deep structures in the vicinity were abandoned, in a similar manner than what we show for the shallow structures in Figure 10 (steps 2 and 3b). A third possibility is that this central part of Dangerous Ground (Figure 1) is a thicker and more rigid continental ribbon that poorly deformed while extension localized south in the NW Borneo Trough and Palawan Trench where crustal thickness is lower. In the next section, we will see how to interpret the extensional events summarized in Figure 10 in the framework of the timing of opening of the SCS.

\subsection{Timing of Extension in the Framework of the South China Sea}

Although we could not perform any correlation of our profile horizons with wells, some steps of the relative chronology detailed in section 5.3 and Figure 10 can be dated in light of what has been previously described in the SCS.

Two recent studies (Peng et al., 2018; Wang et al., 2016) have interpreted seismic profiles acquired close to ours. In Wang et al. (2016), sedimentary units below the erosive surface found within basins A and B (dashed red on Figure 5) are all interpreted as being Mesozoic. The main argument is MCS-derived $P$ waves velocities. Although we agree that this unit is not synrift in the strict sense, regarding the age, we favor previous interpretation by Ding et al. (2013) and Song and Li (2015) with a Cenozoic unit. We find that the main velocity contrast is at the base of this unit (basement, top of the green Mesozoic units in Figure 5) and not at the top of it. Refraction velocities obtained for the light orange unit are actually not excessive for regular compacted Cenozoic sediments. A last hint in favor of a late Oligocene-Early Miocene unconformity is the presence of the carbonate platform in basin C. This interpretation is based on the characteristic continuous subparallel reflectors with low-frequency content of the Nido platforms as described by Steuer et al. (2014). This would assimilate the unconformity at the base of the platform as the Late Oligocene Breakup 
Unconformity and the top of the yellow unit as the Middle Miocene Red Unconformity (blue line in Figure 9) marking the end of opening (see also Morley, 2016).

We therefore tentatively assign a Paleocene to Oligocene age to our brown and light orange units. Our profile does not image any clear Paleogene synrift, indeed usually absent close to the continent-ocean transition of the SW subbasin according to Franke et al. (2014). Overall, this interpretation is in agreement with ages quoted in Madon et al. (2013) constrained by wells south of the Dangerous Ground area. They infer that the faulted and tilted unit lying above basement-quite similar to our light orange unit-is Middle Eocene (43 Ma) to Early Oligocene (30 Ma), with an Early Miocene erosional unconformity. Early Miocene carbonates are also found in the vicinity of OBS 1, where the erosion surface almost outcrops, and around OBS 4, where they were dredged along with the paragneiss (Figure 2; see also Kudrass et al., 1986) at the detachment footwall side boundary of basin C.

Regarding the timing of the detachment, we suggest in Figure 10 (phase $3 \mathrm{~b}$ ) that its activity starts during or just after the "breakup unconformity/erosional event," which is compatible with a breakup propagation attempt similar to Xisha trough (Gao et al., 2016) but probably more recent, as is the failed breakup south of Macclesfield Bank, just before seafloor spreading in the SW subbasin (23 Ma; see Figure 1). We infer that the uplift explaining the significant erosional event is due to the thermal effect of the proximity of the propagation head proceeding toward the SWSB. Just after, subsidence is much larger in basin C due to the crustal detachment activity while basins A and B remain between shallow water and subaerial conditions until the end of extension, when postrift sediments are finally deposited.

The age of the first steps of extension is more difficult to estimate. The very early distributed phase corresponding to densely spaced faulting of the basement would correspond to late Cretaceous based on the comparison with small-offset faults found in the Cretaceous series of the Pearl River Basin (Chan et al., 2010). The later phase related to the steep faults cutting the Mesozoic unit could be associated to the "stretching phase" (Manatschal et al., 2007; Péron-Pinvidic et al., 2013) affecting the basement reflector in the South China Sea, when it can be observed. A good timing for this stretching phase would be Eocene, when extension is widely recorded in the SCS before Oligocene spreading in the NE subbasin (Figure 10, steps 1 to 2).

\section{Conclusion}

Our joint processing and interpretation of MCS reflection and OBS refraction data is able to partially compensate the poor recording of the extension by sediments in this area of Dangerous Ground. We were able to unravel the geometry of a dismantled Mesozoic sedimentary unit and confirm the significance of a crustal detachment. From our interpretation and the relative chronology of events established in the framework of the SCS, we draw several conclusions:

1. The latest phase of extension recorded in Miocene sediments, the only clearly recorded phase, is not very significant when compared to the finite deformation unraveled from the deep seismic image. Most of the extension in the Dangerous Ground area takes place from late Cretaceous to end Oligocene/early Miocene and this main extension is barely recorded in sediments, at least in this profile.

2. Extension seems to heavily reactivate inherited contacts between Paleozoic and Mesozoic units, with block rotation and rafting on décollements when contacts are flat or detachments when contacts are tilted.

3. Structures and basins oblique (NNE-SSW) to the extensional direction (Figure 2) can be explained by the reactivation of contacts bounding the Jurassic-Early Cretaceous arc related granitic plutons now spread in the SCS (Figure 1; see Zhou et al., 2008; Savva et al., 2014). The basin imaged in our study has an orientation in line with the Zhongnan-Lile fault described separating the Eastern and SW subbasins (Ru \& Pigott, 1986; Sibuet et al., 2016; Yao, 1995).

4. The lesser extent of thinning compared to Xisha trough style basins can be explained by the fact that the detachment reactivating the oblique contact is not optimally oriented.

5. Stalling and fast oceanic propagation periods are controlled by far-field dynamics and imply, respectively, homogeneous thinning ahead of the propagator and necking around the propagator (Le Pourhiet et al., 2018). However, locally, reactivation of inherited structures control how deformation is accommodated in both homogenous thinning and near-propagator necking situations. 


\section{Acknowledgments}

Ship and seismic equipment was supplied by GMGS. MCS data processing has been performed at ENS We thank CGG for giving us access to the CGG Geovation 2013 software. The raw seismic data set can be found online (www.geologie.ens.fr/imagerie/) L.Y. was part of a project supported by the Joint Funds of the National Natural Science Foundation of China (grant U1505232). We thank Gaye Bayrakci, Mikael Evain and Weiwei Ding for their helpful comments.

\section{References}

Aurelio, M. A., Forbes, M. T., Taguibao, K. J. L., Savella, R. B., Bacud, J. A., Franke, D., et al. (2014). Middle to Late Cenozoic tectonic events in south and central Palawan (Philippines) and their implications to the evolution of the south-eastern margin of South China Sea: Evidence from onshore structural and offshore seismic data. Marine and Petroleum Geology, 58, 658-673. https://doi.org/10.1016/j. marpetgeo.2013.12.002

Barckhausen, U., Engels, M., Franke, D., Ladage, S., \& Pubellier, M. (2014). Evolution of the South China Sea: Revised ages for breakup and seafloor spreading. Marine and Petroleum Geology, 58, 599-611. https://doi.org/10.1016/j.marpetgeo.2014.02.022

Breitfeld, H. T., Hall, R., Galin, T., Forster, M. A., \& BouDagher-Fadel, M. K. (2017). A Triassic to Cretaceous Sundaland-Pacific subduction margin in West Sarawak, Borneo. Tectonophysics, 694, 35-56. https://doi.org/10.1016/j.tecto.2016.11.034

Briais, A., Patriat, P., \& Tapponnier, P. (1993). Updated interpretation of magnetic anomalies and seafloor spreading stages in the South China Sea: Implications for the Tertiary history of Southeast Asia. Journal of Geophysical Research, 98(B4), 6299-6328. https://doi.org/ $10.1029 / 92 j b 02280$

Cameselle, A. L., Raneor, C. R., Franke, D., \& Barkhausen, U. (2015). The continent-ocean transition on the northwestern South China Sea Basin Research, 29, 73-95. https://doi.org/10.1111/bre.12137

Chan, L. S., Shen, W., \& Pubellier, M. (2010). Polyphase rifting of greater Pearl River Delta region (South China): Evidence for possible rapid changes in regional stress configuration. Journal of Structural Geology, 32(6), 746-754. https://doi.org/10.1016/j.jsg.2010.04.015

Clerc, C., Ringenbach, J. C., Jolivet, L., \& Ballard, J. F. (2017). Rifted margins: Ductile deformation, boudinage, continentward-dipping normal faults and the role of the weak lower crust. Gondwana Research, 53, 20-40. https://doi.org/10.1016/j.gr.2017.04.030

Cullen, A. (2014). Nature and significance of the West Baram and Tinjar Lines, NW Borneo. Marine and Petroleum Geology, 51, $197-209$. https://doi.org/10.1016/j.marpetgeo.2013.11.010

Cullen, A., Reemst, P., Henstra, G., Gozzard, S., \& Ray, A. (2010). Rifting of the South China Sea: New perspectives. Petroleum Geoscience, 16(3), 273-282. https://doi.org/10.1144/1354-079309-908

Cullen, A. B. (2010). Transverse segmentation of the Baram-Balabac Basin, NW Borneo: Refining the model of Borneo's tectonic evolution. Petroleum Geoscience, 16(1), 3-29. https://doi.org/10.1144/1354-079309-828

Ding, W., Franke, D., Li, J., \& Steuer, S. (2013). Seismic stratigraphy and tectonic structure from a composite multi-channel seismic profile across the entire Dangerous Grounds, South China Sea. Tectonophysics, 582, 162-176. https://doi.org/10.1016/j.tecto.2012.09.026

Ding, W., Schnabel, M., Franke, D., Ruan, A., \& Wu, Z. (2012). Crustal Structure across the northwestern margin of South China Sea: Evidence for magma-poor rifting from a wide-angle seismic profile. Acta Geologica Sinica-English Edition, 86(4), 854-866. https://doi. org/10.1111/j.1755-6724.2012.00711.x

Ding, W., Sun, Z., Dadd, K., Fang, Y., \& Li, J. (2018). Structures within the oceanic crust of the central South China Sea basin and their implications for oceanic accretionary processes. Earth and Planetary Science Letters, 488, 115-125. https://doi.org/10.1016/j. epsl.2018.02.011

Ding, W. W., \& Li, J. B. (2016). Conjugate margin pattern of the Southwest Sub-basin, South China Sea: Insights from deformation structures in the continent-ocean transition zone. Geological Journal, 51, 524-534. https://doi.org/10.1002/gj.2733

Faure, M., Lin, W., \& Chen, Y. (2012). Is the Jurassic (Yanshanian) intraplate tectonics of North China due to westward indentation of the North China block? Terra Nova, 24(6), 456-466. https://doi.org/10.1111/ter.12002

Franke, D., Barckhausen, U., Baristeas, N., Engels, M., Ladage, S., Lutz, R., et al. (2011). The continent-ocean transition at the southeastern margin of the South China Sea. Marine and Petroleum Geology, 28(6), 1187-1204. https://doi.org/10.1016/j. marpetgeo.2011.01.004

Franke, D., Barckhausen, U., Heyde, I., Tingay, M., \& Ramli, N. (2008). Seismic images of a collision zone offshore NW Sabah/Borneo Marine and Petroleum Geology, 25(7), 606-624. https://doi.org/10.1016/j.marpetgeo.2007.11.004

Franke, D., Savva, D., Pubellier, M., Steuer, S., Mouly, B., Auxiêtre, J.-L., et al. (2014). The final rifting evolution in the South China Sea. Marine and Petroleum Geology, 58, 704-720. https://doi.org/10.1016/j.marpetgeo.2013.11.020

Gao, J., Wu, S., McIntosh, K., Mi, L., Liu, Z., \& Spence, G. (2016). Crustal structure and extension mode in the northwestern margin of the South China Sea. Geochemistry, Geophysics, Geosystems, 17, 2143-2167. https://doi.org/10.1002/2016gc006247

Gozzard, S., Kusznir, N. J., Franke, D., Cullen, A., Reemst, P., \& Henstra, G. (2018). South China Sea crustal thickness and oceanic lithosphere distribution from satellite gravity inversion. Petroleum Geoscience, The Geological Society of London., 25(1), 112-128. https://doi.org/10.1144/petgeo2016-162

Hall, R. (2013). Contraction and extension in northern Borneo driven by subduction rollback. Journal of Asian Earth Sciences, 76, 399-411. https://doi.org/10.1016/j.jseaes.2013.04.010

Hesse, S., Back, S., \& Franke, D. (2009). The deep-water fold-and-thrust belt offshore NW Borneo: Gravity-driven versus basement-driven shortening. Geological Society of America Bulletin, 121(5-6), 939-953. https://doi.org/10.1130/b26411.1

Hinz, K., \& Schlüter, H. U. (1985). Geology of the Dangerous Grounds, South China Sea, and the continental margin off Southwest Palawan -Results of the Sonne Cruises SO-23 and SO-27. Energy, 10(3-4), 297-315. https://doi.org/10.1016/0360-5442(85)90048-9

Holloway, N. H. (1981). The stratigraphic and tectonic relationship of Reed Bank, North Palawan and Mindoro to the Asia mainland and their significance in the tectonic evolution of the South China Sea basin. Geological Society of Malaysia, 27(6), 173-174.

Holloway, N. H. (1982). North Palawan Block, Philippines-Its relation to Asian mainland and role in evolution of South China Sea. AAPG Bulletin-American Association of Petroleum Geologists, 66(9), 1355-1383.

Huchon, P., Nguyen, T. N. H., \& Chamot-Rooke, N. (1998). Finite extension across the South Vietnam basins from 3D gravimetric modelling: relation to South China Sea kinematics. Marine and Petroleum Geology, 15(7), 619-634. https://doi.org/10.1016/s02648172(98)00031-2

Huchon, P., Nguyen, T. N. H., \& Chamot-Rooke, N. (2001). Propagation of continental break-up in the southwestern South China Sea. In R. C. L. Wilson, R. B. Whitmarsh, B. Taylor, \& N. Froitzheim (Eds.), Non-Volcanic Rifting of Continental Margins: A Comparison of Evidence from Land and Sea (pp. 31-50). Oxford, UK: The Geological Society London. https://doi.org/10.1144/gsl.sp.2001.187.01.03

Huismans, R., \& Beaumont, C. (2011). Depth-dependent extension, two stage breakup and cratonic underplating at rifted margins. Nature, 473(7345), 74-78. https://doi.org/10.1038/nature09988

Hutchison, C. S., \& Vijayan, V. R. (2010). What are the Spratly Islands? Journal of Asian Earth Sciences, 39(5), 371-385. https://doi.org/ 10.1016/j.jseaes.2010.04.013

Ilao, K. A., Morley, C. K., \& Aurelio, M. A. (2018). 3D seismic investigation of the structural and stratigraphic characteristics of the Pagasa Wedge, Southwest Palawan Basin, Philippines, and their tectonic implications. Journal of Asian Earth Sciences, 154, $213-237$. https://doi.org/10.1016/j.jseaes.2017.12.017 
Kudrass, H. R., Wiedicke, M., Cepek, P., Keuzer, H., \& Müller, P. (1986). Mesozoic and Cenozoic rocks dredged from the South China Sea (Reed Bank area) and Sulu Sea and their significance for plate-tectonic reconstructions. Marine and Petroleum Geology, 3(1), 19-30. https://doi.org/10.1016/0264-8172(86)90053-X

Lapierre, H., Jahn, B. M., Charvet, J., \& Yu, Y. W. (1997). Mesozoic felsic arc magmatism and continental olivine tholeiites in Zhejiang province and their relationship with the tectonic activity in southeastern China. Tectonophysics, 274(4), 321-338. https://doi.org/ 10.1016/s0040-1951(97)00009-7

Larsen, H. C., Mohn, G., Nirrengarten, M., Sun, Z., Stock, J., Jian, Z., et al. (2018). Rapid transition from continental breakup to igneous oceanic crust in the South China Sea. Nature Geoscience, 11(10), 782-789. https://doi.org/10.1038/s41561-018-0198-1

Le Pourhiet, L., Chamot-Rooke, N., Delescluse, M., May, D. A., Watremez, L., \& Pubellier, M. (2018). Continental break-up of the South China Sea stalled by far-field compression. Nature Geoscience, 11(8), 605-609. https://doi.org/10.1038/s41561-018-0178-5

Lei, C., Ren, J., Sternai, P., Fox, M., Willett, S., Xie, X., et al. (2015). Structure and sediment budget of Yinggehai-Song Hong basin, South China Sea: Implications for Cenozoic tectonics and river basin reorganization in Southeast Asia. Tectonophysics, 655, 177-190. https://doi.org/10.1016/j.tecto.2015.05.024

Li, C.-F., Xu, X., Lin, J., Sun, Z., Zhu, J., Yao, Y., et al. (2014). Ages and magnetic structures of the South China Sea constrained by deep tow magnetic surveys and IODP Expedition 349. Geochemistry, Geophysics, Geosystems, 15, 4958-4983. https://doi.org/10.1002/2014gc005567

Li, F., Sun, Z., \& Yang, H. (2018). Possible spatial distribution of the Mesozoic volcanic arc in the present-day South China Sea continental margin and its tectonic implications. Journal of Geophysical Research: Solid Earth, 123. https://doi.org/10.1029/2017jb014861

Li, J., Ding, W., Wu, Z., Zhang, J., \& Dong, C. (2012). The propagation of seafloor spreading in the southwestern subbasin, South China Sea. Chinese Science Bulletin, 57(24), 3182-3191. https://doi.org/10.1007/s11434-012-5329-2

Lü, C., Hao, T., Lin, J., \& Qiu, X. (2016). The role of rifting in the development of the continental margins of the southwest subbasin, South China Sea: Insights from an OBS experiment. Marine Geophysical Research, 38(1-2), 105-123. https://doi.org/10.1007/s11001016-9295-y

Madon, M., Ly, K. C., \& Wong, R. (2013). The structure and stratigraphy of deepwater Sarawak, Malaysia: Implications for tectonic evolution. Journal of Asian Earth Sciences, 76, 312-333. https://doi.org/10.1016/j.jseaes.2013.04.040

Manatschal, G., Müntener, O., Lavier, L. L., Minshull, T. A., \& Peron-Pinvidic, G. (2007). Observations from the Alpine Tethys and IberiaNewfoundland margins pertinent to the interpretation of continental breakup. Geological Society of London, Special Publication, 282(1), 291-324. https://doi.org/10.1144/SP282.14

McIntosh, K., Lavier, L., van Avendonk, H., Lester, R., Eakin, D., \& Liu, C.-S. (2014). Crustal structure and inferred rifting processes in the northeast South China Sea. Marine and Petroleum Geology, 58, 612-626. https://doi.org/10.1016/j.marpetgeo.2014.03.012

Milsom, J., Holt, R., Bin Ayub, D., \& Smail, R. (1997). Gravity anomalies and deep structural controls at the Sabah-Palawan margin, South China Sea. Petroleum Geology of Southeast Asia, 126(1), 417-427. https://doi.org/10.1144/gsl.sp.1997.126.01.25

Mohn, G., Manatschal, G., Beltrando, M., Masini, E., \& Kuznir, N. (2012). Necking of continental crust in magma-poor rifted margins: Evidence from the fossil Alpine Tethys margin. Tectonics, 31, TC1012. https://doi.org/10.1029/2011TC002961

Morley, C. K. (2012). Late Cretaceous-Early Palaeogene tectonic development of SE Asia. Earth-Science Reviews, 115(1-2), 37-75. https://doi.org/10.1016/j.earscirev.2012.08.002

Morley, C. K. (2016). Major unconformities/termination of extension events and associated surfaces in the South China Seas: Review and implications for tectonic development. Journal of Asian Earth Sciences, 120, 62-86. https://doi.org/10.1016/j.jseaes.2016.01.013

Peng, X., Shen, C., Mei, L., Zhao, Z., \& Xie, X. (2018). Rift-drift transition in the Dangerous Grounds, South China Sea. Marine Geophysical Researches. https://doi.org/10.1007/s11001-018-9353-8

Péron-Pinvidic, G., \& Manatschal, G. (2008). The final rifting evolution at deep magma-poor passive margins from Iberia-Newfoundland: A new point of view. International Journal of Earth Sciences, 98(7), 1581-1597. https://doi.org/10.1007/s00531-008-0337-9

Péron-Pinvidic, G., Manatschal, G., \& Osmundsen, P. T. (2013). Structural comparison of archetypal Atlantic rifted margins: A review of observations and concepts. Marine and Petroleum Geology, 43, 21-47. https://doi.org/10.1016/j.marpetgeo.2013.02.002

Pichot, T., Delescluse, M., Chamot-Rooke, N., Pubellier, M., Sun, G., Méresse, F., et al. (2014). Deep crustal structure of the conjugate margins of the SW South China Sea from wide-angle refraction seismic data. Marine and Petroleum Geology, 58, 627-643. https://doi. org/10.1016/j.marpetgeo.2013.10.008

Pubellier, M., \& Morley, C. K. (2014). The basins of Sundaland (SE Asia): Evolution and boundary conditions. Marine and Petroleum Geology, 58, 555-578. https://doi.org/10.1016/j.marpetgeo.2013.11.019

Pubellier, M., Savva, D., Aurelio, M., \& Sapin, F. (2016). Structural map of the South China Sea, Commission for the Geological Map of the World, Paris, France. https://doi.org/10.14682/2017STRUCTUSCS.

Ru, K., \& Pigott, J. D. (1986). Episodic Rifting and subsidence in the South China Sea. The American Association of Petroleum Geologists Bulletin, 70(9), 1,136-1,155.

Sapin, F., Pubellier, M., Lahfid, A., Janots, D., Aubourg, C., \& Ringenbach, J.-C. (2011). Onshore record of the subduction of a crustal salient: Example of the NW Borneo Wedge. Terra Nova, 23(4), 232-240. https://doi.org/10.1111/j.1365-3121.2011.01004.x

Savva, D., Méresse, F., Pubellier, M., Chamot-Rooke, N., Lavier, L., Po, K. W., et al. (2013). Seismic evidence of hyper-stretched crust and mantle exhumation offshore Vietnam. Tectonophysics, 608, 72-83. https://doi.org/10.1016/j.tecto.2013.07.010

Savva, D., Pubellier, M., Franke, D., Chamot-Rooke, N., Méresse, F., Steuer, S., \& Auxietre, J. L. (2014). Different expressions of rifting on the South China Sea margins. Marine and Petroleum Geology, 58, 579-598. https://doi.org/10.1016/j.marpetgeo.2014.05.023

Schlüter, H.U., Hinz, K., \& Block, M. (1996). Tectono-stratigraphic terranes and detachment faulting of the South China Sea and Sulu Sea. Marine Geology, 130(1-2), 39-78. https://doi.org/10.1016/0025-3227(95)00137-9

Sibuet, J. C., Yeh, Y.-C., \& Li, C.-S. (2016). Geodynamics of the South China Sea. Tectonophysics, 692, 98-119. https://dx.doi.org/10.1016/j. tecto.2016.02.022

Song, T., \& Li, C.-F. (2015). Rifting to drifting transition of the Southwest Subbasin of the South China Sea. Marine Geophysical Research, 36(2-3), 167-185. https://doi.org/10.1007/s11001-015-9253-0

Steuer, S., Franke, D., Méresse, F., Savva, D., Pubellier, M., \& Auxiêtre, J.-L. (2014). Oligocene-Miocene carbonates and their role for constraining the rifting and collision history of the Dangerous Grounds, South China Sea. Marine and Petroleum Geology, 58, 644-657. https://doi.org/10.1016/j.marpetgeo.2013.12.010

Sun, Z., Zhong, Z., Keep, M., Zhou, D., Cai, D., Li, X., et al. (2009). 3D analogue modeling of the South China Sea: A discussion on breakup pattern. Journal of Asian Earth Sciences, 34(4), 544-556. https://doi.org/10.1016/j.jseaes.2008.09.002

Sun, Z., Zhou, D., Zhong, Z., Xia, B., Qiu, X., Zeng, Z., \& Jiang, J. (2006). Ressearch on the dynamics of the South China Sea opening: Evidence from analogue modeling. Science in China Series D: Earth Sciences, 49(10), 1053-1069. https://doi.org/10.1007/s11430-006$1053-6$ 
Taylor, B., \& Hayes, D. E. (1980). The tectonic evolution of the South China Basin. In D. E. Hayes (Ed.), The Tectonic and Geologic Evolution of Southeast Asian Seas and Islands, (pp. 89-104). Washington, DC: American Geophysical Union. https://doi.org/10.1029/GM023p0089

Taylor, B., \& Hayes, D. E. (1983). Origin and history of the South China Sea Basin. In D. E. Hayes (Ed.), The Tectonic and Geologic Evolution of Southeast Asian Seas and Islands: Part 2, (pp. 23-56). Washington, DC: American Geophysical Union. https://doi.org/10.1029/ GM027p0023

Vijayan, V. R., Foss, C., \& Stagg, H. (2013). Crustal character and thickness over the Dangerous Grounds and beneath the Northwest Borneo Trough. Journal of Asian Earth Sciences, 76, 389-398. https://doi.org/10.1016/j.jseaes.2013.06.004

Wang, Y., Qiu, Y., Yan, P., Zheng, H., Liu, H., \& Wang, J. (2016). Seismic evidence for Mesozoic strata in the northern Nansha waters, South China Sea. Tectonophysics, 677-678, 190-198. https://doi.org/10.1016/j.tecto.2016.04.003

Wei, X., Ruan, A., Zhao, M., Qiu, X., Wu, Z., \& Niu, X. (2015). Shear wave velocity structure of Reed Bank, southern continental margin of the South China Sea. Tectonophysics, 644-645, 151-160. https://doi.org/10.1016/j.tecto.2015.01.006

Weissel, J. K., \& Karner, G. D. (1989). Flexural uplift of rift flank due to mechanical unloading of the lithosphere during extension. Jounral of Geophysical Research, 94(B10), 13,919-13,950. https://doi.org/10.1029/JB094iB10p13919

Wernicke, B. (1985). Unifor-sense normal simple shear of the continental lithosphere. Canadian Journal of Earth Sciences, 22(1), 108-125. https://doi.org/10.1139/e85-009

Yan, P., Wang, L., \& Wang, Y. (2014). Late Mesozoic compressional folds in Dongsha Waters, the northern margin of the South China Sea. Tectonophysics, 615-616, 213-223. https://doi.org/10.1016/j.tecto.2014.01.009

Yan, Q., Shi, X., \& Li, N. (2011). Oxygen and lead isotope characteristics of granitic rocks from the Nansha block (South China Sea): Implications for their petrogenesis and tectonic affinity. Island Arc, 20(2), 150-159. https://doi.org/10.1111/j.1440-1738.2010.00754.x

Yan, Q., Shi, X., Liu, J., Wang, K., \& Bu, W. (2010). Petrology and geochemistry of Mesozoic granitic rocks from the Nansha micro-block, the South China Sea: Constraints on the basement nature. Journal of Asian Earth Sciences, 37(2), 130-139. https://doi.org/10.1016/j. jseaes.2009.08.001

Yao, B. (1995). Characteristics and tectonic meaning of Zhongnan-Lile Fault. Geological Research of South China Sea, 7, 1-14.

Yao, Y., Liu, H., Yang, C., Han, B., Tian, J., Yin, Z., et al. (2012). Characteristics and evolution of Cenozoic sediments in the Liyue Basin, SE South China Sea. Journal of Asian Earth Sciences, 60, 114-129. https://doi.org/10.1016/j.jseaes.2012.08.003

Yu, J., Yan, P., Wang, Y., Zhang, J., Qiu, Y., Pubellier, M., \& Delescluse, M. (2018). Seiscmic evidence for tectonically dominated seafloor spreading in the Southwest Sub-basin of the South China Sea. Geochemistry, Geophysics, Geosystems, 19(9), 3459-3477. https://doi.org/ $10.1029 / 2018$ GC007819

Yu, Z., Li, J., Ding, W., Zhang, J., Ruan, A., \& Niu, X. (2017). Crustal structure of the Southwest Subbasin, South China Sea, from wideangle seismic tomography and seismic reflection imaging. Marine Geophysical Research, 38(1-2), 85-104. https://doi.org/10.1007/ s11001-016-9284-1

Zahirovic, S., Seton, M., \& Mueller, R. D. (2014). The Cretaceous and Cenozoic tectonic evolution of Southeast Asia. Solid Earth, 5(1), 227-273. https://doi.org/10.5194/se-5-227-2014

Zelt, C. A., \& Smith, R. B. (1992). Seismic traveltime inversion for 2-D crustal velocity structure. Geophysical Journal International, 108(1), 16-34. https://doi.org/10.1111/j.1365-246X.1992.tb00836.x

Zhou, D., Sun, Z., Chen, H.-Z., Xu, H.-H., Wang, W.-Y., Pang, X., et al. (2008). Mesozoic paleogeography and tectonic evolution of South China Sea and adjacent areas in the context of Tethyan and Paleo-Pacific interconnections. Island Arc, 17(2), 186-207. https://doi.org/ 10.1111/j.1440-1738.2008.00611.x

Zhou, X. M., Sun, T., Shen, W. Z., Shu, L. S., \& Niu, Y. L. (2006). Petrogenesis of Mesozoic granitoids and volcanic rocks in South China: A response to tectonic evolution. Episodes, 29(1), 26-33. 